\title{
Experimental and computational study of trace element distribution between orthopyroxene and anhydrous silicate melt: substitution mechanisms and the effect of iron
}

\author{
Mirjam van Kan Parker • Axel Liebscher • \\ Dirk Frei · Jelle van Sijl · Wim van Westrenen • \\ Jon Blundy · Gerhard Franz
}

Received: 20 April 2009/Accepted: 4 August 2009/Published online: 22 August 2009

(c) The Author(s) 2009. This article is published with open access at Springerlink.com

\begin{abstract}
Although orthopyroxene (Opx) is present during a wide range of magmatic differentiation processes in the terrestrial and lunar mantle, its effect on melt trace element contents is not well quantified. We present results of a combined experimental and computational study of trace element partitioning between Opx and anhydrous silicate melts. Experiments were performed in air at atmospheric pressure and temperatures ranging from 1,326 to $1,420^{\circ} \mathrm{C}$ in the system $\mathrm{CaO}-\mathrm{MgO}-\mathrm{Al}_{2} \mathrm{O}_{3}-\mathrm{SiO}_{2}$ and subsystem $\mathrm{CaO}-$ $\mathrm{MgO}-\mathrm{SiO}_{2}$. We provide experimental partition coefficients for a wide range of trace elements (large ion lithophile: $\mathrm{Li}$, $\mathrm{Be}, \mathrm{B}, \mathrm{K}, \mathrm{Rb}, \mathrm{Sr}, \mathrm{Cs}, \mathrm{Ba}, \mathrm{Th}, \mathrm{U}$; rare earth elements, REE: La,
\end{abstract}

Communicated by J. Hoefs.

M. van Kan Parker $(\varangle) \cdot$ J. van Sijl $\cdot$ W. van Westrenen Faculty of Earth and Life Science, VU University Amsterdam, De Boelelaan 1085, 1081 HV Amsterdam, The Netherlands e-mail: mirjam.van.kan@falw.vu.nl

A. Liebscher - G. Franz

Institut für Angewandte Geowissenschaften, Technische Universität Berlin, Ernst-Reuter-Platz 1, 10587 Berlin, Germany

A. Liebscher - D. Frei

GFZ German Research Centre for Geosciences, Telegrafenberg, 14473 Potsdam, Germany

D. Frei

Geological Survey of Denmark and Greenland (GEUS),

Øster Voldgade 10, 1350 Copenhagen K, Denmark

J. Blundy

CETSEI, Department of Earth Sciences, University of Bristol, Wills Memorial Building, Queens Road, Bristol BS8 1RJ, United Kingdom
$\mathrm{Ce}, \mathrm{Nd}, \mathrm{Sm}, \mathrm{Y}, \mathrm{Yb}, \mathrm{Lu}$; high field strength: Zr, Nb, Hf, Ta, Ti; transition metals: Sc, V, Cr, Co) for use in petrogenetic modelling. REE partition coefficients increase from $D_{\mathrm{La}}^{\mathrm{Opx}-\mathrm{melt}} \sim 0.0005$ to $D_{\mathrm{Lu}}^{\mathrm{Opx}-\text { melt }} \sim 0.109, D$ values for highly charged elements vary from $D_{\mathrm{Th}}^{\mathrm{Opx}-\mathrm{melt}} \sim 0.0026$ through $D_{\mathrm{Nb}}^{\mathrm{Opx}-\mathrm{melt}} \sim 0.0033$ and $D_{\mathrm{U}}^{\mathrm{Opx}-\mathrm{melt}} \sim 0.0066$ to $D_{\mathrm{Ti}}^{\mathrm{Opx}-\text { melt }} \sim$ 0.058 , and are all virtually independent of temperature. $\mathrm{Cr}$ and $\mathrm{Co}$ are the only compatible trace elements at the studied conditions. To elucidate charge-balancing mechanisms for incorporation of REE into Opx and to assess the possible influence of $\mathrm{Fe}$ on Opx-melt partitioning, we compare our experimental results with computer simulations. In these simulations, we examine major and minor trace element incorporation into the end-members enstatite $\left(\mathrm{Mg}_{2} \mathrm{Si}_{2} \mathrm{O}_{6}\right)$ and ferrosilite $\left(\mathrm{Fe}_{2} \mathrm{Si}_{2} \mathrm{O}_{6}\right)$. Calculated solution energies show that $\mathrm{R}^{2+}$ cations are more soluble in Opx than $\mathrm{R}^{3+}$ cations of similar size, consistent with experimental partitioning data. In addition, simulations show charge balancing of $\mathrm{R}^{3+}$ cations by coupled substitution with $\mathrm{Li}^{+}$on the $\mathrm{M} 1$ site that is energetically favoured over coupled substitution involving $\mathrm{Al}-\mathrm{Si}$ exchange on the tetrahedrally coordinated site. We derived best-fit values for ideal ionic radii $r_{0}$, maximum partition coefficients $D_{0}$, and apparent Young's moduli $E$ for substitutions onto the Opx M1 and M2 sites. Experimental $r_{0}$ values for $\mathrm{R}^{3+}$ substitutions are $0.66-0.67 \AA$ for $\mathrm{M} 1$ and $0.82-0.87 \AA$ for M2. Simulations for enstatite result in $r_{0}=0.71-0.73 \AA$ for M1 and $\sim 0.79-0.87 \AA$ for M2. Ferrosilite $r_{0}$ values are systematically larger by $\sim 0.05 \AA$ for both M1 and M2. The latter is opposite to experimental literature data, which appear to show a slight decrease in $r_{0}^{\mathrm{M} 2}$ in the presence of $\mathrm{Fe}$. Additional systematic studies in $\mathrm{Fe}$ bearing systems are required to resolve this inconsistency and to develop predictive Opx-melt partitioning models for use in terrestrial and lunar magmatic differentiation models. 
Keywords Orthopyroxene - Partition coefficient . Experimental determination - Computer simulations . Substitution mechanisms

\section{Introduction}

Orthopyroxene (Opx) is a common rock-forming silicate in the Earth's crust and upper mantle, and a major constituent of the Moon's mantle. It is a residual phase during melting and crystallisation processes including MORB generation on Earth (e.g. O'Hara 1968; Green 1971) and magma ocean crystallisation on the Moon (e.g. Taylor and Jakes 1974; Snyder et al. 1992; Shearer and Papike 1999).

The effect of Opx on the trace element budget of coexisting melts is not well quantified. It is generally assumed that both Opx and olivine have little effect compared to, e.g., clinopyroxene and garnet due to their low mineral-melt partition coefficients: $D$ values, where $D$, the Nernst solid-liquid partition coefficient, is defined as the concentration ratio by weight between mineral and melt, e.g.

$D_{i}^{\mathrm{Opx}-\mathrm{melt}}=\frac{c_{i}^{\mathrm{Opx}}}{c_{i}^{\text {melt }}}$

However, during crystallisation of the first three quarters of the lunar magma ocean, Opx and olivine were the only main crystallising phases (Snyder et al. 1992), and therefore play a fundamental role in the trace element evolution.

Published studies of Opx-melt partitioning (Barnes 1986; Colson et al. 1988; Colson and Gust 1989; Nielsen et al. 1992; Kennedy et al. 1993; Schwandt and McKay 1998; Canil 1999; Green et al. 2000; McDade et al. 2003; Adam and Green 2006; Klemme et al. 2006; Lee et al. 2007; Bédard 2007; Frei et al. 2009) show enormous variations in $D$ values (Fig. 1), e.g. four orders of magnitude for Ba. Trace element partitioning between phases in equilibrium depends on pressure $(P)$, temperature $(T)$ and composition $(x)$ of mineral and co-existing melt, as well as oxygen fugacity $\left(f \mathrm{O}_{2}\right)$ in the case of multivalent cations, and $P-T$ $x-f \mathrm{O}_{2}$ variations likely explain most of the variability.

Unfortunately, with the exception of the study of Frei et al. (2009), systematic experimental studies of Opx-melt partitioning that cover a substantial $P-T-x-f \mathrm{O}_{2}$ range are not available. As a result, no predictive thermodynamic model is available for Opx-melt partitioning as there is for clinopyroxene (Wood and Blundy 1997) or garnet (van Westrenen and Draper 2007), hindering quantitative petrogenetic modelling of terrestrial and lunar mantle melting and crystallisation processes.

Amongst previously published Opx-melt partitioning studies, the contributions of Adam and Green (2006) and Frei et al. (2009) are the only two using a large number of trace elements including the large ion lithophile (LILE), high field strength (HFSE) and rare earth elements (REE), and that consider the effects of the M1 and M2 structural lattice sites separately. They focus on trace element partitioning between Opx and hydrous basanitic melt (Adam and Green 2006) and anhydrous silicate melt (Frei et al. 2009). Here, we present a follow-up study to Frei et al. (2009) with Opx-melt partition coefficients for the LILE ( $\mathrm{Li}, \mathrm{Be}, \mathrm{B}, \mathrm{K}, \mathrm{Rb}, \mathrm{Sr}, \mathrm{Cs}, \mathrm{Ba}$, Th and $\mathrm{U}$ ), the REE ( $\mathrm{La}, \mathrm{Ce}, \mathrm{Nd}, \mathrm{Sm}, \mathrm{Y}, \mathrm{Yb}, \mathrm{Lu})$, the $\operatorname{HFSE}(\mathrm{Zr}, \mathrm{Nb}$, $\mathrm{Hf}, \mathrm{Ta}$ and $\mathrm{Ti}$ ), and the transition metals ( $\mathrm{Sc}, \mathrm{V}, \mathrm{Cr}$ and $\mathrm{Co}$ ), derived from experiments performed in synthetic basaltic systems at atmospheric pressure. We combine experimental results with computer simulations to (1) elucidate incorporation mechanisms for $\mathrm{R}^{3+}$ cations $\mathrm{Al}, \mathrm{Cr}, \mathrm{Sc}$, and REE into the Opx structure and (2) assess the possible effect of $\mathrm{Fe}$ on Opx-melt partition coefficients.

\section{Methods}

Experimental and analytical techniques

Experiments were performed in the system $\mathrm{CaO}-\mathrm{MgO}-$ $\mathrm{Al}_{2} \mathrm{O}_{3}-\mathrm{SiO}_{2}$ (CMAS) and subsystem $\mathrm{CaO}-\mathrm{MgO}-\mathrm{SiO}_{2}$ (CMS). Run conditions and starting materials were chosen according to previous experimental work by Longhi and Boudreau (1980) in CMAS and by Longhi (1987) in CMS (Table 1) to ensure the formation of ortho-enstatite (the enstatite structure that is also stable at elevated $P$ ), as opposed to proto-enstatite (which can also be stable at ambient $P$ and elevated T). Longhi (1987) used various different compositions, we used the two labelled '13$61+25 \mathrm{Wo}$ ' and ' $20-55+18 \mathrm{Wo}+4 \mathrm{Mg}$ ' and refer to them as 'A87' and 'B87', respectively.

Starting materials were synthesised in $1 \mathrm{~g}$ batches by mixing high purity powdered oxides $\left(\mathrm{SiO}_{2}, \mathrm{Al}_{2} \mathrm{O}_{3}\right.$ and $\mathrm{MgO}$ ) and $\mathrm{CaCO}_{3}$. After grinding, decarbonation and fusion, the resulting glass powders were doped with various amounts of $\mathrm{Li}, \mathrm{Be}, \mathrm{B}, \mathrm{K}, \mathrm{Rb}, \mathrm{Sr}, \mathrm{Cs}, \mathrm{Ba}$, Th, U, La, Ce, Nd, Sm, Y, Yb, Lu, Zr, Nb, Hf, Ta, Ti, Sc, V, Cr and Co using AAS standard solutions. Concentrations were chosen to ensure analytical precision of better than $10 \%$ based on ion yields and realistic count times (Hinton 1990). After drying, denitrification, fusion and grinding under acetone, the resulting fine glass powders were used as starting material. All materials were nominally water-free.

Experiments were carried out in air using vertical quench furnaces at the Department of Earth Sciences, University of Bristol, UK. Approximately $300 \mathrm{mg}$ starting material was loaded into cylindrical Pt capsules, $1.6 \mathrm{~mm}$ in diameter and $\sim 5 \mathrm{~mm}$ long and welded shut. For each experimental run, two sample capsules with different bulk compositions were suspended in the hot spot of the furnace 
Fig. 1 Compilation of partition coefficients $D_{i}$ for Opx showing results of this study and the experimentally determined range (Colson et al. 1988; Kennedy 1993; Dunn and Sen 1994; Schwandt and McKay 1998; McDade et al. 2003; Klemme et al. 2006; Frei et al. 2009)

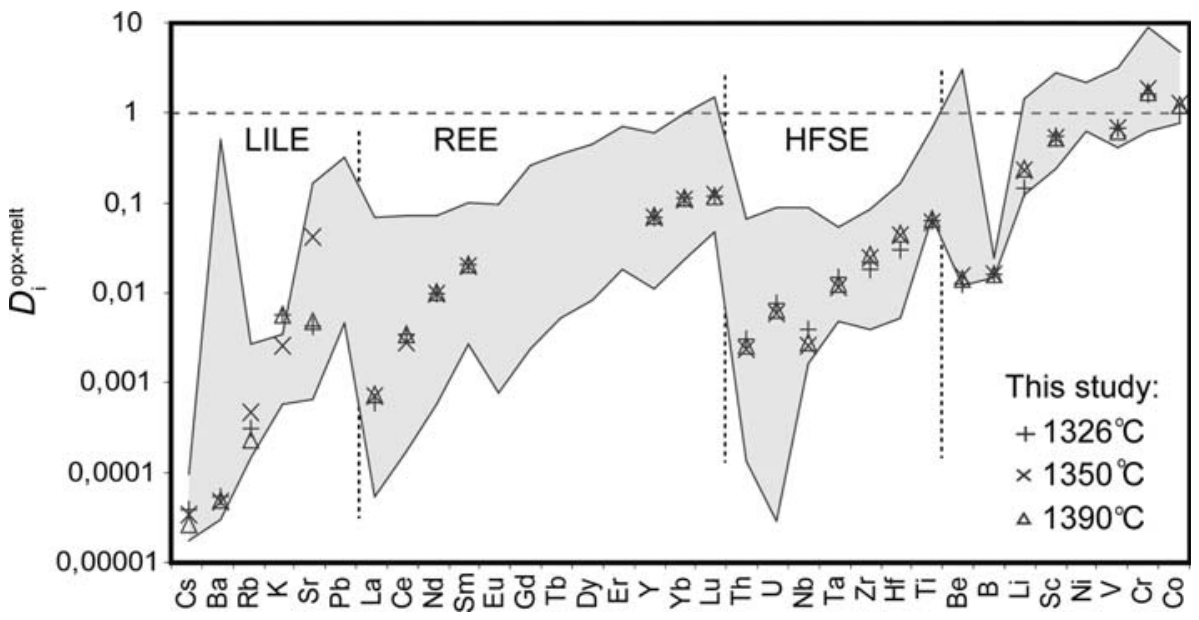

Table 1 Nominal (gravimetric) major element composition (wt\%) of starting materials prior to doping, according to Longhi 1987 (=L87) and Longhi and Boudreau 1980 (=L\&B)

\begin{tabular}{lcrccc}
\hline Source: & \multicolumn{2}{c}{ L87 } & & \multicolumn{2}{c}{ L\&B } \\
\cline { 2 - 3 } \cline { 5 - 6 } Mix: & A87 & B87 & & A & B \\
\hline $\mathrm{SiO}_{2}$ & 56.5 & 54.1 & & 58.1 & 62.1 \\
$\mathrm{Al}_{2} \mathrm{O}_{3}$ & 3.8 & 6.0 & - & - \\
$\mathrm{MgO}$ & 27.9 & 29.5 & 30.5 & 26.5 \\
$\mathrm{CaO}$ & 11.8 & 10.4 & & 11.4 & 11.4 \\
Total & 100 & 100 & & 100 & 100 \\
\hline
\end{tabular}

using a Pt wire. Temperature was monitored during the experiment using a PtRh6-PtRh30 (type B) thermocouple placed adjacent to the sample capsules. After holding the samples $30^{\circ} \mathrm{C}$ above the run temperature for $1 \mathrm{~h}$, the samples were slowly cooled to the final run temperature. After $60-96 \mathrm{~h}$ at the final run temperature, the capsules were quenched in water, mounted in Petropoxy resin, sectioned and polished for subsequent analysis.

Textures of experimental run products were examined by petrographic microscope (Zeiss DSM 962) and scanning electron microscope (SEM, Philips XL 40) at the German Research Centre for Geosciences (GFZ) Potsdam and the Geological Survey of Denmark and Greenland, Copenhagen (GEUS). X-ray diffraction (XRD) analysis was used to check the crystal structure of the experimentally produced Opx grains. Phase identification was performed in Copenhagen using the ThermoNoran Voyager 2.7 energy dispersive X-ray analysis system attached to the SEM. Major element chemistry of all run products was determined on carbon-coated polished mounts, using an electron microprobe analyser (EMPA), in wavelength dispersive mode at GFZ Potsdam (Cameca SX 100) and the University of Copenhagen (JEOL JXA-8200 Superprobe). In both electron microprobes, an accelerating voltage of $15 \mathrm{kV}$ and beam current of $15 \mathrm{nA}$ were employed. For mineral analysis, the beam diameter was $3 \mu \mathrm{m}$, whilst a slightly defocused beam of 5-10 $\mu \mathrm{m}$ diameter was used for silicate glass analysis. Standards used for calibration were wollastonite $(\mathrm{Ca}, \mathrm{Si})$, olivine $(\mathrm{Mg})$, and spinel $(\mathrm{Al})$. Raw data obtained in Potsdam and Copenhagen were reduced using the ZAF correction schemes of Pouchou and Pichoir (1985) and Bence and Albee (1968), respectively.

Trace element concentrations were determined by secondary ion mass spectrometry (SIMS) on the Cameca IMS$4 \mathrm{f}$ ion probe at the Department of Geology and Geophysics, University of Edinburgh, using the same polished mounts previously used for EMPA analysis. Prior to analysis, samples were cleaned ultrasonically in methanol and coated with Au to optimise surface conductivity. The primary beam was $10.69 \mathrm{keV} \mathrm{O}^{-}$ions, with a sample current of 6-12 nA corresponding to a spatial resolution of $\sim 30$ $60 \mu \mathrm{m}$. The secondary ion accelerating voltage was $4,500 \mathrm{~V}$ with an offset of $75 \mathrm{~V}$ and energy window of $\pm 20 \mathrm{eV}$ to reduce molecular ion transmission. The following isotopes were measured and ratioed to ${ }^{30} \mathrm{Si}$ as determined by EMPA: ${ }^{7} \mathrm{Li},{ }^{9} \mathrm{Be},{ }^{11} \mathrm{~B},{ }^{39} \mathrm{~K},{ }^{42} \mathrm{Ca},{ }^{45} \mathrm{Sc},{ }^{47} \mathrm{Ti}$, ${ }^{51} \mathrm{~V},{ }^{52} \mathrm{Cr},{ }^{53} \mathrm{Cr},{ }^{59} \mathrm{Co},{ }^{58} \mathrm{Ni},{ }^{85} \mathrm{Rb},{ }^{88} \mathrm{Sr},{ }^{89} \mathrm{Y},{ }^{90} \mathrm{Zr},{ }^{93} \mathrm{Nb}$, ${ }^{121} \mathrm{Sn},{ }^{123} \mathrm{Sn},{ }^{122} \mathrm{Sb},{ }^{133} \mathrm{Cs},{ }^{138} \mathrm{Ba},{ }^{139} \mathrm{La},{ }^{140} \mathrm{Ce},{ }^{143} \mathrm{Nd}$, ${ }^{149} \mathrm{Sm},{ }^{171} \mathrm{Yb},{ }^{175} \mathrm{Lu},{ }^{178} \mathrm{Hf},{ }^{181} \mathrm{Ta},{ }^{208} \mathrm{~Pb},{ }^{232} \mathrm{U}$ and ${ }^{238} \mathrm{Th}$. Mass 130.5 was measured as background and all analyses reported in this study have zero background counts. Count times were adjusted to ensure a statistical precision of better than $10 \%$ relative for all measured isotopes. Calibration was performed under similar operation conditions using NIST SRM 610 glass for all analyses. Accuracy of SIMS was assessed from regular analysis of secondary standards including a clinopyroxene separate from San Carlos (SC 8804), clinopyroxene from Kilbourne Hole (KH 1) and a gem-quality diopside from Madagascar.

Experimental charges were analysed for $\mathrm{Sr}, \mathrm{Cs}, \mathrm{Ba}$, and $\mathrm{Pb}$ at GEUS Copenhagen, by laser ablation-inductively coupled plasma-mass spectrometry (LA-ICP-MS). For a 
detailed description of the experimental procedure employed for LA-ICP-MS analysis, see Ziemann et al. (2005) and Liebscher et al. (2007).

\section{Computational techniques}

Computer simulations of the energetics of trace element incorporation into the M1 and M2 structural sites of Opx end-members enstatite $\left(\mathrm{Mg}_{2} \mathrm{Si}_{2} \mathrm{O}_{6}\right)$ and ferrosilite $\left(\mathrm{Fe}_{2} \mathrm{Si}_{2} \mathrm{O}_{6}\right)$ were carried out using static lattice energy calculations. Calculations are performed in the static limit (at zero pressure and zero Kelvin in the absence of lattice vibrations) with the General Utility Lattice Program (GULP; Gale 1997). The structure of pyroxenes (general formula $\mathrm{XYZ}_{2} \mathrm{O}_{6}$ ) is essentially described by alternating tetrahedral and octahedral layers, parallel to the (100) plane. Y atoms occupy the smaller octahedral M1 site, X atoms the larger six- to eightfold coordinated M2 site and Z atoms (usually mostly $\mathrm{Si}$, minor $\mathrm{Al}$ ) occupy the tetrahedral $\mathrm{T}$ site.

Natural $\mathrm{Mg}-\mathrm{Fe}$ pyroxenes commonly crystallise in the Pbca space group. The $\mathrm{Mg}$ pyroxenes are referred to as ortho-enstatite or enstatite, and the Fe pyroxenes as orthoferrosilite or ferrosilite. For our simulations, we assumed the Pbca space group, with six-fold coordination with oxygen for both M1 and M2 lattice sites.

Simulations use a Born ionic model, which assigns integral ionic charges based on accepted chemical valences (e.g. $2^{+}$for $\mathrm{Fe}$ and $\mathrm{Mg}, 4^{+}$for $\mathrm{Si}$ ). The shell model of Dick and Overhauser (1958) is used to take account of oxygen ion polarisation.

The lattice energy, $U_{\text {lat }}$, is divided into a Coulombic term, corresponding to long-range electrostatic interactions between adjacent atoms and a non-Coulombic term, corresponding to short-range repulsions. Cation-oxygen non-Coulombic interactions are described by two-body Buckingham potentials, and a three-body $\mathrm{O}-\mathrm{Si}-\mathrm{O}$ bond bending term is added to improve the description of silica tetrahedra. The full set of interatomic potential and shell model parameters used is given in Table 2. Previous studies showed the applicability of these potentials for simulation of a wide range of oxides and silicates including Opx (Purton et al. 1996, 1997a; van Westrenen et al. 2000a, b; Corgne et al. 2003).

For all substitutions, initial unrelaxed $\left(U_{\operatorname{def}(i)}\right)$ and final relaxed $\left(U_{\operatorname{def}(\mathrm{f})}\right)$ defect energies are calculated for homoand heterovalent substitutions on M1 and M2. The homovalent substitutions consider replacement of $\mathrm{Mg}^{2+}$ or $\mathrm{Fe}^{2+}$ by another $\mathrm{R}^{2+}$ cation. The heterovalent case studies substitutions of $\mathrm{R}^{3+}$ cations and evaluates two charge-balancing mechanisms: (1) two $\mathrm{R}^{3+}$ cations replacing a $\mathrm{Mg}^{2+}$ or $\mathrm{Fe}^{2+}$ and a tetrahedrally coordinated $\mathrm{Si}^{4+}$ (Tschermakite-type) and (2) one $\mathrm{R}^{3+}$ cation and one $\mathrm{R}^{+}$cation [either the relatively smaller $\mathrm{Li}^{+}$(on M1) or the larger $\mathrm{Rb}^{+}$(on M2)], substituting for two $\mathrm{Mg}^{2+}$ or two $\mathrm{Fe}^{2+}$. In addition, two simulations on $\mathrm{La}$ and $\mathrm{Lu}$ incorporation into enstatite were performed to assess the energetics of charge-balancing $\mathrm{R}^{3+}$ via $\mathrm{Mg}$ vacancy formation.

Defect energies relate to the energetics of the solid phase only. To realistically simulate trace element partitioning between minerals and melt, it is important to evaluate solution energies ( $U_{\text {sol }}$, e.g. van Westrenen et al. 2000a). These include a simplified description of the contribution of the removal and substitution of a trace element (J) from the melt accompanied by insertion of a major element into the melt:

$$
\begin{aligned}
& \mathrm{JO}(\text { liquid })+\mathrm{MgMgSi}_{2} \mathrm{O}_{6}(\text { solid }) \\
& \quad \rightarrow \mathrm{MgJSi}_{2} \mathrm{O}_{6}(\text { solid })+\mathrm{MgO}(\text { liquid }) \\
& U_{\text {sol }}=U_{\text {def }, \mathrm{f}\left(\mathrm{MgJSi}_{2} \mathrm{O}_{6}\right)}+U_{\text {lat }(\mathrm{MgO})}-U_{\text {lat }(\mathrm{JO})}
\end{aligned}
$$

In other words, our simulations assume that the local environments of major and trace elements in the melts coexisting with enstatite or ferrosilite are identical to their local environment in the corresponding binary oxides. For a detailed discussion of this approach, see van Westrenen et al. (2000a).

\section{Lattice strain model}

Both experimental $D$ values and computational solution energy data are interpreted using the so-called crystal lattice strain model (Blundy and Wood 1994). The model has been applied to a large number of minerals such as clinopyroxene (Wood and Blundy 1997), garnet (e.g. van Westrenen et al. 1999, 2000a, b, 2001), titanite (Prowatke and Klemme 2005), zoisite (Frei et al. 2003) and apatite (Prowatke and Klemme 2006). In addition, the lattice strain model was successfully applied to Opx-melt partitioning data by Green et al. (2000), Adam and Green (2006), Bédard (2007) and Frei et al. (2009). The model is based on the observations of Onuma et al. (1968), who showed that the behaviour of $D_{i}$ versus $r_{i}$ for series of homovalent cations is near parabolic with maxima corresponding to the size of the crystal lattice site(s) on which substitution occurs. It combines these observations with the lattice strain model of Brice (1975), relating lattice strain energy $U_{\text {strain }}$ associated with the insertion of a trace element with radius $r_{i}$ into a site with ideal radius $r_{0}$, to the elasticity of the site (Young's modulus, $E$ ) and the size misfit between substituent and ideal site cations $\left(r_{i}-r_{0}\right)$ :

$U_{\text {strain }}=4 \pi E N_{\mathrm{A}}\left[\frac{1}{2} r_{0}\left(r_{i}-r_{0}\right)^{2}+\frac{1}{3}\left(r_{i}-r_{0}\right)^{3}\right]$

Assuming this crystal lattice strain energy term dominates mineral-melt partitioning energetics, Blundy and Wood (1994) derived 
Table 2 Interatomic potential parameters, corresponding oxide lattice energies and relevant atomic radii used in this study (two-body potentials: $\varphi=A \exp (-r / \rho)-C / r^{6}$ with $r$ the inter-ionic distance; threebody potentials: $\varphi=(1 / 2)$ $K_{\mathrm{B}}\left(\theta-\theta_{0}\right)^{2}$ with $\theta$ the $\mathrm{O}-\mathrm{Si}-\mathrm{O}$ bond angle)

Parameters from: P, Purton et al. (1997b); S, Sanders et al. (1984); C, Catlow et al. (1982); $\mathrm{La}, \mathrm{Lb}, \mathrm{L} 1$ and L2, Lewis and Catlow 1985-method a, b, c1 and $\mathrm{c} 2$, respectively. Ionic radii are based on six fold coordination with oxygen (Shannon 1976)

$\mathrm{L}^{*}=$ refitted lattice energy value using the oxygen potential and charge from Lewis and Catlow (1985) and structural information from: Bashir et al. (2002) (Sr); Cunningham (1963) (Eu)

${ }^{\text {a }}$ Lattice energies for $\mathrm{R}^{2+}$ cations atoms are calculated using simple oxides. For $\mathrm{R}^{3+}$ cations they are calculated using the bixbyite structure

\begin{tabular}{lrllll}
\hline $\mathrm{Interaction}^{2-}$ & $A\left(\mathrm{~kJ} \mathrm{~mol}^{-1}\right)$ & $\rho(\AA)$ & $C\left(\mathrm{~kJ} \mathrm{~mol}^{-1}\right)$ & $U_{\text {lat }}\left(\mathrm{kJ} \mathrm{mol}^{-1}\right)^{\mathrm{a}}$ & $r_{i}(\AA)$ \\
\hline $\mathrm{Li}^{+} / \mathrm{O}^{2-}$ & 34,157 & 0.3239 & 0 & $-2,941^{\mathrm{P}}$ & 0.76 \\
$\mathrm{Rb}^{+} / \mathrm{O}^{2-}$ & 88,706 & 0.3772 & 0 & $-2,090^{\mathrm{P}}$ & 1.52 \\
$\mathrm{O}^{2-} / \mathrm{O}^{2-}$ & $2,196,392$ & 0.149 & $2,690^{\mathrm{S}}$ & & \\
$\mathrm{Ca}^{2+} / \mathrm{O}^{2-}$ & 105,207 & 0.3437 & 0 & $-3,469^{\mathrm{L} 2}$ & 1.00 \\
$\mathrm{Ni}^{2+} / \mathrm{O}^{2-}$ & 152,688 & 0.2882 & 0 & $-4,022^{\mathrm{L} 2}$ & 0.69 \\
$\mathrm{Mn}^{2+} / \mathrm{O}^{2-}$ & 97,199 & 0.3262 & 0 & $-3,743^{\mathrm{L} 2}$ & 0.83 \\
$\mathrm{Fe}^{2+} / \mathrm{O}^{2-}$ & 116,515 & 0.3084 & 0 & $-3,880^{\mathrm{L} 2}$ & 0.78 \\
$\mathrm{Co}^{2+} / \mathrm{O}^{2-}$ & 143,927 & 0.2951 & 0 & $-3,948^{\mathrm{L} 2}$ & 0.745 \\
$\mathrm{Mg}^{2+} / \mathrm{O}^{2-}$ & 137,829 & 0.2945 & 0 & $-3,986^{\mathrm{L} 2}$ & 0.72 \\
$\mathrm{Cd}^{2+} / \mathrm{O}^{2-}$ & 83,778 & 0.3500 & 0 & $-3,531^{\mathrm{La}}$ & 0.95 \\
$\mathrm{Sr}^{2+} / \mathrm{O}^{2-}$ & 135,733 & 0.3500 & 0 & $-3,257^{\mathrm{L}}$ & 1.18 \\
$\mathrm{Eu}^{2+} / \mathrm{O}^{2-}$ & 120,242 & 0.3556 & 0 & $-3,259^{\mathrm{L}}$ & 1.17 \\
$\mathrm{Ba}^{2+} / \mathrm{O}^{2-}$ & 89,895 & 0.3949 & 0 & $-3,023^{\mathrm{L} 1}$ & 1.35 \\
$\mathrm{Cr}^{3+} / \mathrm{O}^{2-}$ & 167,315 & 0.301 & 0 & $-14,924^{\mathrm{L} 1}$ & 0.615 \\
$\mathrm{Al}^{3+} / \mathrm{O}^{2-}$ & 140,898 & 0.29912 & 0 & $-15,538^{\mathrm{C}}$ & 0.535 \\
$\mathrm{Sc}^{3+} / \mathrm{O}^{2-}$ & 125,375 & 0.3312 & 0 & $-14,017^{\mathrm{Lb}}$ & 0.745 \\
$\mathrm{Lu}^{3+} / \mathrm{O}^{2-}$ & 129,975 & 0.3430 & 0 & $-13,341^{\mathrm{Lb}}$ & 0.861 \\
$\mathrm{La}^{3+} / \mathrm{O}^{2-}$ & 138,910 & 0.3651 & 0 & $-12,228^{\mathrm{Lb}}$ & 1.032 \\
$\mathrm{Yb}^{3+} / \mathrm{O}^{2-}$ & 126,357 & 0.3462 & 0 & $-13,262^{\mathrm{Lb}}$ & 0.868 \\
$\mathrm{Eu}^{3+} / \mathrm{O}^{2-}$ & 131,027 & 0.3556 & 0 & $-12,754^{\mathrm{Lb}}$ & 0.947 \\
$\mathrm{Nd}^{3+} / \mathrm{O}^{2-}$ & 133,140 & 0.3601 & 0 & $-12,527^{\mathrm{Lb}}$ & 0.983 \\
$\mathrm{Si}^{4 \pm} / \mathrm{O}^{2-}$ & 123,878 & 0.32052 & 1,028 & $-13,125^{\mathrm{S}}$ & \\
\hline $\mathrm{nt}^{2-}$ & & 0 & &
\end{tabular}

Interaction $^{\mathrm{S}} \quad \mathrm{O}^{2-} / \mathrm{Si}^{4+} / \mathrm{O}^{2-}$

$K_{\mathrm{B}}\left(\mathrm{kJ} \mathrm{mol}{ }^{-1} \mathrm{rad}^{-2}\right) \quad 202$

$\theta_{0}\left(^{\circ}\right) \quad 109.47$

Shell parameters $\mathrm{s}$

Ion $\quad \mathrm{O}^{2-}$

Shell charge (lel) $\quad-2.86902$

$k\left(\mathrm{~kJ} \mathrm{~mol}^{-1} \AA^{-2}\right) \quad 7,229$

$$
\begin{aligned}
& D_{i}^{\text {mineral-melt }}=D_{0} \exp \left(\frac{-U_{\text {strain }}}{R T}\right) \\
& =D_{0} \exp \left(\frac{-4 \pi E N_{\mathrm{A}}\left[(1 / 2) r_{0}\left(r_{i}-r_{0}\right)^{2}+(1 / 3)\left(r_{i}-r_{0}\right)^{3}\right]}{R T}\right)
\end{aligned}
$$

where $N_{\mathrm{A}}$ is Avogadro's number, $R$ the gas constant, $D_{i}$ is the measured partition coefficient for element $i$, and $D_{0}$ the maximum partition coefficient for an ideally sized element.

Because Opx has two similarly sized structural sites in which trace elements mainly concentrate, $U_{\text {strain }}$ and $D_{i}^{\text {Opx-melt }}$ can be written as the sum of individual $U_{\text {strain }}$ and $D$ values for the M1 and M2 lattice sites:

$U_{\text {strain }}=U_{\text {strain(M1) }}+U_{\text {strain(M2) }}$

$D_{i}^{\mathrm{Opx}-\mathrm{melt}}=\frac{c_{i}^{\mathrm{M} 1}+c_{i}^{\mathrm{M} 2}}{c_{i}^{\mathrm{melt}}}=D_{i}^{\mathrm{M} 1 \text {-melt }}+D_{i}^{\mathrm{M} 2-\text { melt }}$
Combining Eqs. 4 and 6 gives:

$$
\begin{aligned}
U_{\text {strain }}= & 4 \pi N_{\mathrm{A}}\left(E^{\mathrm{M} 1}\left[\frac{1}{2} r_{0}\left(r_{i}-r_{0}\right)^{2}+\frac{1}{3}\left(r_{i}-r_{0}\right)^{3}\right]^{\mathrm{M} 1}\right. \\
& \left.+E^{\mathrm{M} 2}\left[\frac{1}{2} r_{0}\left(r_{i}-r_{0}\right)^{2}+\frac{1}{3}\left(r_{i}-r_{0}\right)^{3}\right]^{\mathrm{M} 2}\right)
\end{aligned}
$$

Similarly combining Eqs. 5 and 7 gives:

$$
\begin{aligned}
& D_{i}^{\text {Opx }- \text { melt }} \\
& =D_{0}^{\mathrm{M} 1} \exp \frac{4 \pi E^{\mathrm{M} 1} N_{\mathrm{A}}\left[(1 / 2) r_{0}^{\mathrm{M} 1}\left(r_{i}-r_{0}^{\mathrm{M} 1}\right)^{2}+(1 / 3)\left(r_{i}-r_{0}^{\mathrm{M} 1}\right)^{3}\right]}{R T} \\
& +D_{0}^{\mathrm{M} 2} \exp \frac{4 \pi E^{\mathrm{M} 2} N_{\mathrm{A}}\left[(1 / 2) r_{0}^{\mathrm{M} 2}\left(r_{i}-r_{0}^{\mathrm{M} 2}\right)^{2}+(1 / 3)\left(r_{i}-r_{0}^{\mathrm{M} 2}\right)^{3}\right]}{R T}
\end{aligned}
$$

Computational data for $\mathrm{R}^{3+}$ cations partitioning, and experimental results for $\mathrm{R}^{3+}$ and $\mathrm{R}^{4+}$ cations, were fitted to 
Table 3 Experimental run conditions and products

\begin{tabular}{|c|c|c|c|c|c|}
\hline Starting mix & Run & $T\left({ }^{\circ} \mathrm{C}\right)$ & $\begin{array}{l}\text { Run } \\
\text { time (h) }\end{array}$ & $\begin{array}{l}\text { Run } \\
\text { products }^{\mathrm{a}}\end{array}$ & Notes $^{\mathrm{b}}$ \\
\hline $\mathrm{L} \& \mathrm{~B}(\mathrm{~A})$ & A-1 & 1,420 & 96 & $\mathrm{gl}$ & $100 \%$ melt \\
\hline $\mathbf{L} \& B$ & A-2 & 1,390 & 60 & en + fo + gl & $90 \%$ melt \\
\hline L\&B (B) & B1 & 1,350 & 84 & en + gl & $75 \%$ melt \\
\hline L87 (A87) & L87-I & 1,340 & 60 & fo $+\mathrm{gl}$ & $90 \%$ melt \\
\hline L87 (B87) & L87-II & 1,340 & 60 & fo $+\mathrm{gl}$ & $85 \%$ melt \\
\hline L87 (A87) & L87-III & 1,326 & 60 & en + cpx + fo + gl & $60 \%$ melt \\
\hline L87 (B87) & L87-IV & 1,326 & 60 & fo $+\mathrm{gl}$ & $85 \%$ melt \\
\hline
\end{tabular}

Experiments used to determine enstatite-melt partition coefficients are marked in bold; for Mix A and B, see Table 1

${ }^{a}$ Run products are enstatite (en), clinopyroxene (cpx), forsterite (fo) and glass (gl)

b Melt phase (=glass) proportion in wt\% estimated visually or from least squares regression of phase compositions and starting materials

Eqs. 8 and 9, respectively, using a non-linear least square Levenberg-Marquardt fitting routine (Press et al. 1992). Experimental data fits are weighted using the error on $D$ as weighting factor and minimising

$\chi^{2}=\sum\left[\left(D_{i}^{\text {observed }}-D_{i}^{\text {calculated }}\right) / D_{i}^{\text {observed }}\right]^{2}$.

\section{Results}

\section{Experimental results}

Orthopyroxene was identified in three of the seven experimental runs. XRD analysis confirmed the structure to be that of ortho-enstatite. The melt fraction is 0.90 at $1,390^{\circ} \mathrm{C}, 0.75$ at $1,350^{\circ} \mathrm{C}$ and 0.60 at $1,326^{\circ} \mathrm{C}$ and additional phases are forsterite at 1,390 and $1,326^{\circ} \mathrm{C}$ and clinopyroxene at $1,326^{\circ} \mathrm{C}$ (Table 3; Fig. 2). Major and trace element compositions of run products are listed in Table 4. Opx is almost pure enstatite $\left(\mathrm{En}_{0.97} \mathrm{Di}_{0.03}\right.$ at 1,390 and $1,350^{\circ} \mathrm{C}$ and $\mathrm{En}_{0.95} \mathrm{Di}_{0.05}$ at $1,326^{\circ} \mathrm{C}$ ) with a negligible Tschermakite component. Its major element compositions are similar for 1,390 and $1,350^{\circ} \mathrm{C}$ (Table 4 ), whilst at $1,326^{\circ} \mathrm{C}$ it has $0.8-1.0 \mathrm{wt} \%$ less $\mathrm{MgO}$ and 0.8 wt $\%$ more $\mathrm{CaO} . \mathrm{SiO}_{2}$ is constant at $59.3 \pm 0.1 \mathrm{wt} \%$. The melt is boninitic with $\mathrm{SiO}_{2}=56.8-$ $60.6 \mathrm{wt} \%, \quad \mathrm{MgO}=19.7-27.1 \mathrm{wt} \%, \quad$ and $\mathrm{CaO}=15.2-$ $16.4 \mathrm{wt} \%$. Both melt and enstatite contained minor amounts of $\mathrm{Na}$ (100-300 ppm) even though starting compositions were nominally Na-free. Trace element compositions are homogeneous for all run products (Table 4). Melts have higher trace element concentrations than Opx, with the exception of $\mathrm{Co}$ at 1,350 and $1,390^{\circ} \mathrm{C}$ and $\mathrm{Cr}$.

Based on trace element concentrations of the melt and co-existing Opx, we calculated $D$ values (Table 5). Our data fit within the published range of partition coefficients for Opx (Fig. 1).

For the limited temperature range of our experiments, the effect of temperature on $D$ is negligible. Fractionation of the
HREE from the LREE, e.g. $D_{\mathrm{La}}^{\mathrm{Opx}-m e l t} / D_{\mathrm{Lu}}^{\mathrm{Opx}-m e l t}$, is between $0.005\left(1,326^{\circ} \mathrm{C}\right)$ and $0.006\left(1,390^{\circ} \mathrm{C}\right) . D_{\mathrm{Zr}}^{\mathrm{Opx}-\text { melt }} / D_{\mathrm{Hf}}^{\mathrm{Opx}-\text { melt }}$ ranges from $0.551\left(1,350^{\circ} \mathrm{C}\right)$ to $0.615\left(1,326^{\circ} \mathrm{C}\right)$, $D_{\mathrm{Th}}^{\mathrm{Opx}-\mathrm{melt}} / D_{\mathrm{U}}^{\mathrm{Opx}-\mathrm{melt}}$ ranges from $0.385\left(1,350^{\circ} \mathrm{C}\right)$ to 0.400 $\left(1,390^{\circ} \mathrm{C}\right)$, and $D_{\mathrm{Nb}}^{\mathrm{Opx}-\mathrm{melt}} / D_{\mathrm{Ta}}^{\mathrm{Opx}-\mathrm{melt}}$ from $0.254\left(1,326^{\circ} \mathrm{C}\right)$ to $0.213\left(1,390^{\circ} \mathrm{C}\right)$, indicating that $\mathrm{Opx}$ fractionates $\mathrm{Hf}, \mathrm{U}$ and $\mathrm{Ta}$ from $\mathrm{Zr}$, Th and $\mathrm{Nb}$, respectively.

Figure 3 shows our experimental results presented in Onuma diagrams. Partition coefficients for $\mathrm{R}^{3+}$ and $\mathrm{R}^{4+}$ cations show approximately double-parabolic behaviour, consistent with the presence of distinct M1 and M2 sites in Opx-the Opx M site should hence not be considered as a single site in Opx-melt partitioning models (cf. Bédard 2007). The calculated $D$ values for the $\mathrm{R}^{3+}$ cations were fitted with Eq. 9 (curves in Fig. 3). Due to the limited number of $\mathrm{R}^{4+}$ cations, their $r_{0}^{\mathrm{M} 2}$ was fixed at the values obtained for the $\mathrm{R}^{3+}$ cations for the corresponding runs. Note that although in air $U$ is expected to be present as $\mathrm{U}^{6+}$, it is used for the $\mathrm{R}^{4+}$ cation fits because our measured values of $D_{\mathrm{U}}$ are very close to the results of Frei et al. (2009) for experiments at reducing conditions in which $\mathrm{U}^{4+}$ was stable. The resulting values for $D_{0}, E$, and $r_{0}$ are given in Table 6. Fitting the $\mathrm{R}^{+}$and $\mathrm{R}^{2+}$ cations with Eq. 9 was unsuccessful due to the limited number of data points and the poorly defined individual parabolas for M1 and M2. Fits to the M1 site for the $\mathrm{R}^{3+}$ cations in the 1,350 and $1,390^{\circ} \mathrm{C}$ experiments need to be viewed with caution, because of the large uncertainty in the measured aluminium partition coefficient. In addition, because the distribution of Al between the Opx M1 and T sites is not known, the indicated $D_{\mathrm{Al}}^{\mathrm{M} 1}$ are maximum values (indicated by a downpointing arrow in Fig. 3). However, it is clear that $D_{\mathrm{Al}}^{\mathrm{M} 1}<1$, imposing an important constraint on these fits. $\mathrm{Al}$ data are, therefore, included in the fitting procedure.

The fitted values show $D_{0}^{\mathrm{M} 1}>D_{0}^{\mathrm{M} 2}$ and $D_{0}^{3+}>D_{0}^{4+}$. For the apparent Young's modulus values, we find that $E^{\mathrm{M} 1}>E^{\mathrm{M} 2}$ values are between $998-2,123 \mathrm{GPa}\left(3^{+}\right)$and 

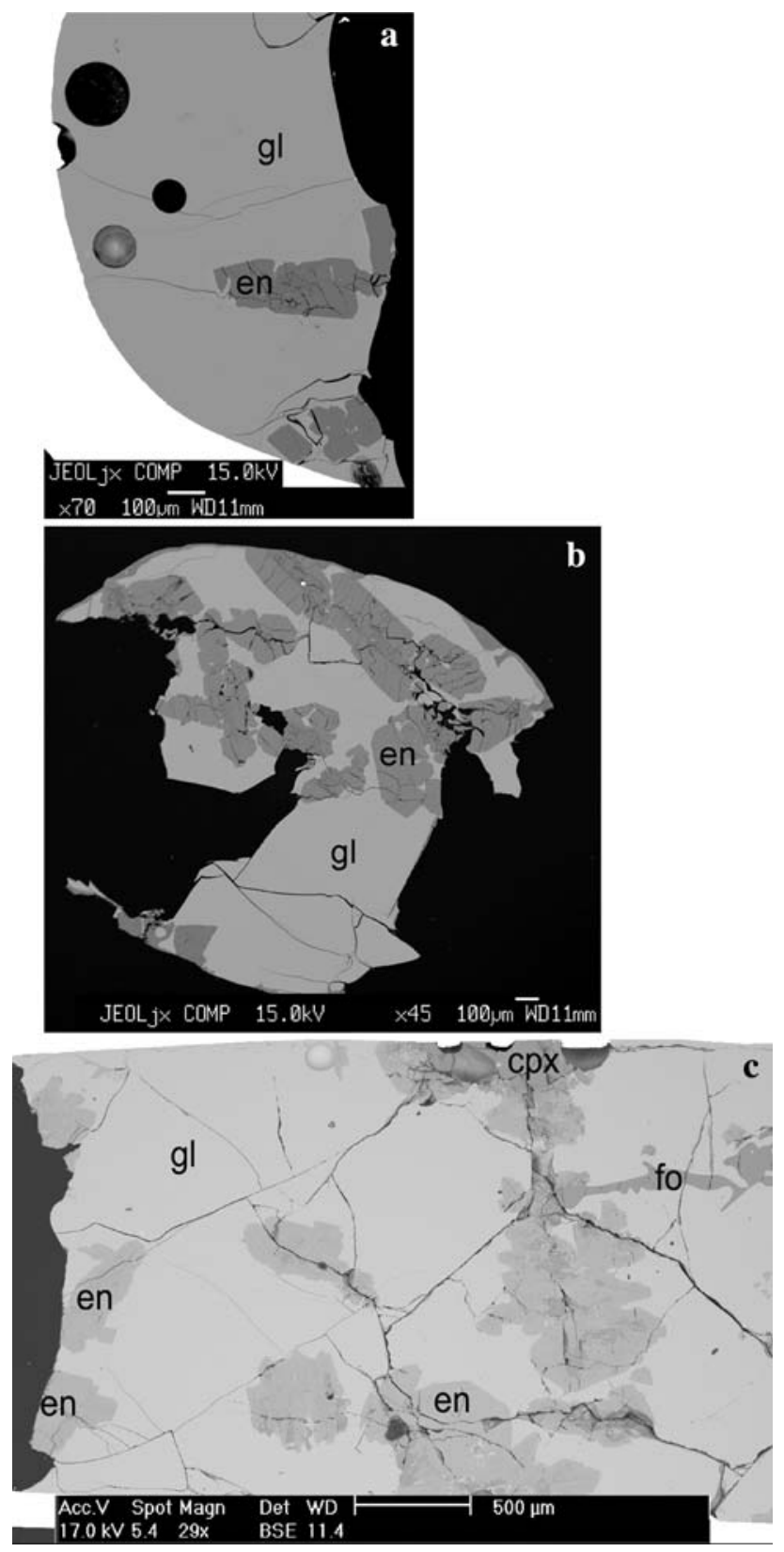

Fig. 2 Backscatter electron (BSE) images of run products in experiments at $1,390^{\circ} \mathrm{C}(\mathbf{a}), 1,350^{\circ} \mathrm{C}$ (b) and $1,326^{\circ} \mathrm{C}$ (c). En enstatite, $g l$ glass, cpx clinopyroxene, $f o$ forsterite. Forsterite is present, but was not photographed in the $1,390^{\circ} \mathrm{C}$ run

2,360-2,773 GPa $\left(4^{+}\right)$for M1 and between 388-667 GPa $\left(3^{+}\right)$and $454-810 \mathrm{GPa}\left(4^{+}\right)$for $\mathrm{M} 2 . E^{\mathrm{M} 1(4+)}>E^{\mathrm{M} 1(3+)}$ and $E^{\mathrm{M} 2(4+)}>E^{\mathrm{M} 2(3+)}$ are consistent with observations in other mineral-melt systems (e.g. Blundy and Wood 1994).

The optimum ionic radii for $\mathrm{R}^{3+}$ cations are 0.66$0.67 \AA$ for $r_{0}^{\mathrm{M} 1}$ and $0.82-0.87 \AA$ for $r_{0}^{\mathrm{M} 2}$, the latter increases with $T$. For the $\mathrm{R}^{4+}$ cations, $r_{0}^{\mathrm{M} 1}$ is $0.65-0.66 \AA$. We note that the values for $r_{0}^{\mathrm{M} 1}$ are almost identical to the sixfold coordinated radius of $\mathrm{Ti}^{3+}(0.67 \AA$, Shannon 1976). Combined with the observation that $D_{0}^{\mathrm{M} 1}$ is larger for $\mathrm{R}^{3+}$ cations than for cations of any other formal charge, this suggests that $\mathrm{Ti}^{3+}$ is the most compatible element in Opx, with a predicted $D$ of $\sim 5$. At oxygen fugacities sufficiently low to stabilise $\mathrm{Ti}^{3+}$, as suggested for the Moon (e.g. Papike et al. 2005), Opx will preferentially incorporate $\mathrm{Ti}^{3+}$ over $\mathrm{Ti}^{4+}$ by one to two orders of magnitude.

Computational results

\section{Orthopyroxene structure}

The calculated lattice parameters for pure enstatite and ferrosilite are given in Table 7. Lattice parameters are reproduced to within $3.1 \%$ of the experimentally determined values. The bulk moduli deviate between -3.2 and $1.3 \%$ of the measured values at room conditions for enstatite and ferrosilite, respectively (Table 7). These differences are mainly related to our static limit $(T=0 \mathrm{~K})$ simulations versus experimental values that were determined at room $T$. Our calculated unit cell volumes are therefore smaller.

\section{Solution energies}

Solution energies for the smallest $\mathrm{R}^{2+}$ and $\mathrm{R}^{3+}$ cations considered here, e.g. $\mathrm{Ni}^{2+}, \mathrm{Al}^{3+}, \mathrm{Cr}^{3+}$ and $\mathrm{Sc}^{3+}$, are consistently lower for substitution onto the M1 site than for substitution onto the M2 site (Fig. 4). Since lower solution energy corresponds to higher solubility this implies that the M1 site is the preferred site for these cations, whilst the M2 site is preferred by the other, larger cations. The radius at which substitutions on M1 and M2 become identical in solution energy varies with trace element charge. $\mathrm{R}^{2+}$ cations show a cross-over in site preference at $0.72 \AA$ (enstatite) or $0.78 \AA$ (ferrosilite), $\mathrm{R}^{3+}$ cations at $0.86-0.95 \AA$ depending on the substitution mechanism (Table 8).

Substitutions of $\mathrm{R}^{2+}$ have the lowest solution energies followed by heterovalent substitutions involving $\mathrm{Li}^{+}$. The heterovalent substitutions involving $\mathrm{Rb}^{+}$and coupled $\mathrm{Al}-$ Si exchange clearly lead to higher solution energy values (Fig. 4). Solution energies for $\mathrm{Lu}$ and $\mathrm{La}$ incorporation into enstatite with the aid of $\mathrm{Mg}$ vacancy formation are even higher $\left(U_{\mathrm{sol}(\mathrm{Lu})} \sim 840 \mathrm{~kJ} / \mathrm{mol}\right.$ and $\left.U_{\mathrm{sol}(\mathrm{La})} \sim 815 \mathrm{~kJ} / \mathrm{mol}\right)$ showing that this is not an efficient charge-balancing mechanism in Opx.

Minimum solution energies show double-parabolic behaviour when plotted versus ionic radius, with a kink between $\mathrm{Sc}$ and the REE, broadly consistent with the experiments. Fits to Eq. 8 (curves in Fig. 4, see Table 8 for fit parameters) show a clear difference in $r_{0}$ between the M1 and M2 lattice sites. Simulations also show a difference in ionic radius between enstatite and ferrosilite substitutions, with ferrosilite substitutions systematically showing $r_{0}$ larger by $\sim 0.05 \AA$, for both M1 and $\mathrm{M} 2$, compared to enstatite substitutions. 


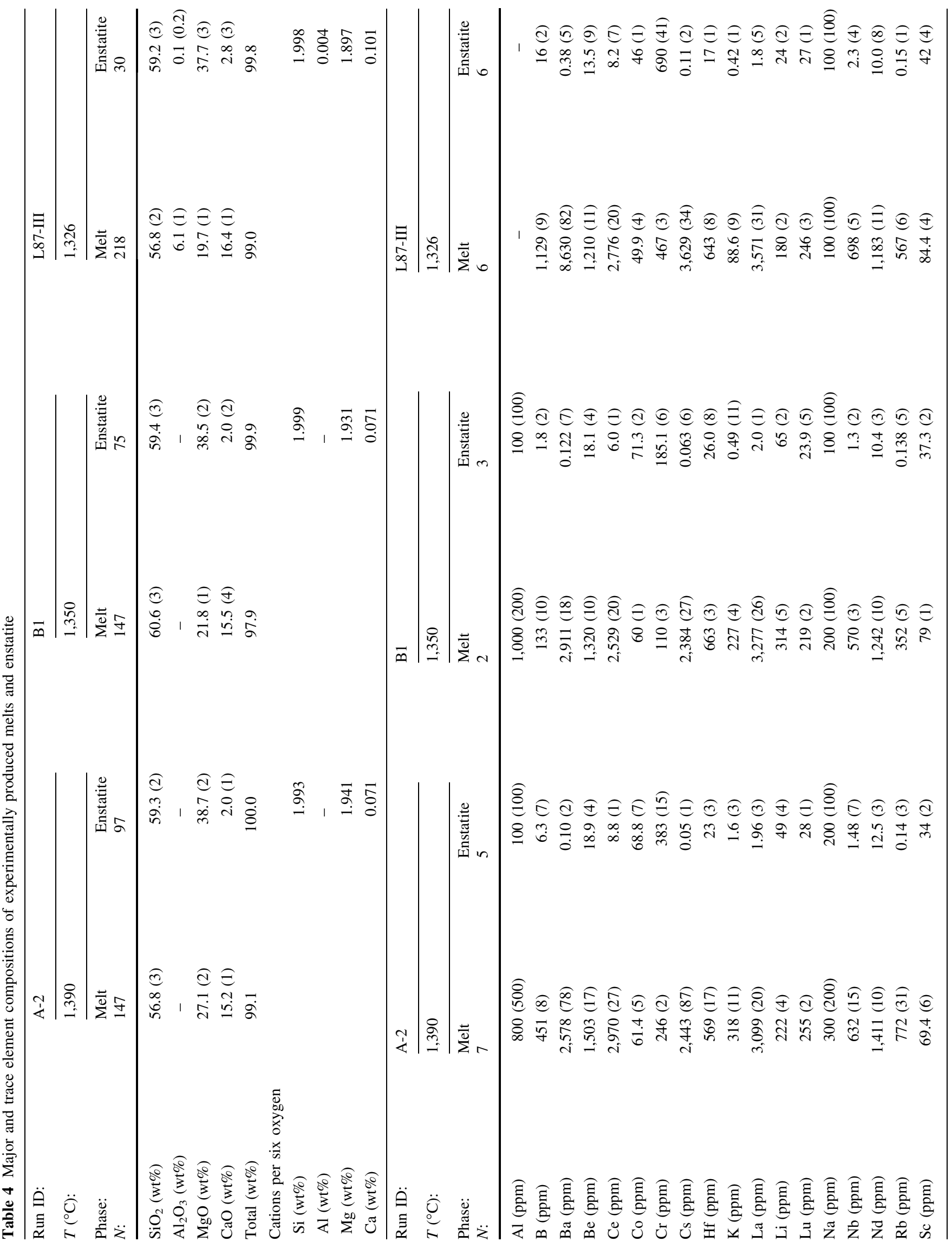




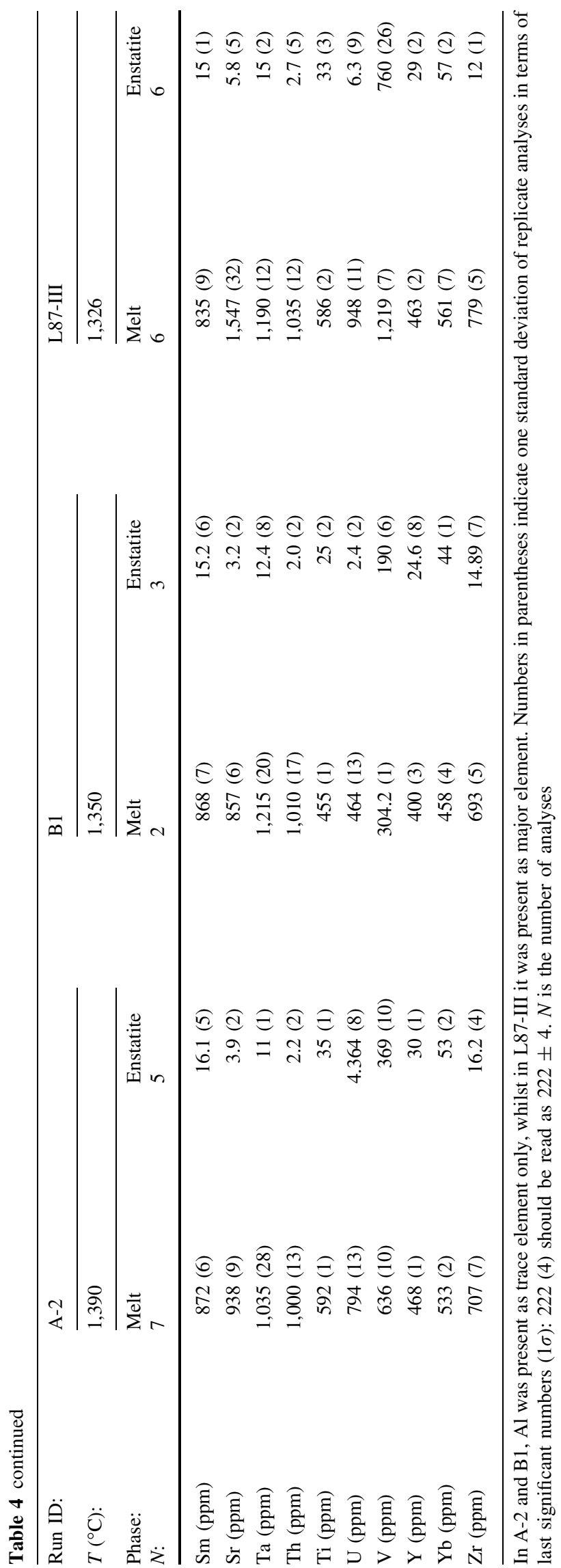

Table 5 Enstatite-melt trace element partition coefficients $D$

\begin{tabular}{|c|c|c|c|}
\hline $\begin{array}{l}\text { Run: } \\
T\left({ }^{\circ} \mathrm{C}\right):\end{array}$ & $\begin{array}{l}\text { A-2 } \\
1,390\end{array}$ & $\begin{array}{l}\text { B1 } \\
1,350\end{array}$ & $\begin{array}{l}\text { L87-III } \\
1,326\end{array}$ \\
\hline B & $0.014(2)$ & $0.014(2)$ & $0.014(2)$ \\
\hline $\mathrm{Ba}$ & $0.000040(8)$ & $0.000039(2)$ & $0.000044(6)$ \\
\hline $\mathrm{Be}$ & $0.0126(3)$ & 0.0137 (3) & $0.0111(8)$ \\
\hline $\mathrm{Ce}$ & $0.00298(5)$ & $0.00235(4)$ & $0.0030(2)$ \\
\hline Co & $1.12(1)$ & $1.18(1)$ & $0.92(3)$ \\
\hline $\mathrm{Cr}$ & $1.56(7)$ & $1.69(4)$ & $1.48(9)$ \\
\hline $\mathrm{Cs}$ & 0.000021 & 0.000027 & 0.000031 \\
\hline $\mathrm{Hf}$ & $0.040(5)$ & $0.039(1)$ & $0.026(2)$ \\
\hline $\mathrm{K}$ & $0.0049(9)$ & $0.0022(5)$ & $0.0048(12)$ \\
\hline $\mathrm{La}$ & $0.00063(1)$ & $0.00060(4)$ & $0.0005(2)$ \\
\hline $\mathrm{Li}$ & $0.22(2)$ & $0.208(7)$ & $0.13(1)$ \\
\hline $\mathrm{Lu}$ & $0.108(5)$ & $0.109(2)$ & $0.108(5)$ \\
\hline $\mathrm{Nb}$ & $0.00234(1)$ & $0.0022(3)$ & $0.0033(5)$ \\
\hline $\mathrm{Nd}$ & 0.0089 (2) & $0.0084(3)$ & 0.0085 (7) \\
\hline $\mathrm{Rb}$ & $0.00019(5)$ & $0.00039(1)$ & $0.00026(2)$ \\
\hline $\mathrm{Sc}$ & 0.48 (3) & $0.474(6)$ & $0.50(5)$ \\
\hline $\mathrm{Sm}$ & $0.0184(6)$ & $0.0175(7)$ & $0.018(1)$ \\
\hline $\mathrm{Sr}$ & $0.0041(2)$ & $0.0037(2)$ & 0.0037 (3) \\
\hline $\mathrm{Ta}$ & $0.011(1)$ & $0.0102(7)$ & $0.013(2)$ \\
\hline $\mathrm{Th}$ & $0.0022(2)$ & $0.0020(2)$ & $0.0026(4)$ \\
\hline $\mathrm{Ti}$ & $0.058(2)$ & $0.055(4)$ & $0.056(5)$ \\
\hline $\mathrm{U}$ & $0.00550(9)$ & $0.0052(5)$ & $0.0066(10)$ \\
\hline $\mathrm{V}$ & $0.58(2)$ & $0.62(2)$ & $0.62(2)$ \\
\hline $\mathrm{Y}$ & $0.065(2)$ & $0.061(2)$ & $0.062(4)$ \\
\hline $\mathrm{Yb}$ & $0.100(4)$ & $0.096(3)$ & $0.101(4)$ \\
\hline $\mathrm{Zr}$ & $0.023(6)$ & 0.0215 (2) & $0.016(2)$ \\
\hline
\end{tabular}

Numbers in parentheses indicate one standard deviation of replicate analyses in terms of last significant numbers $(1 \sigma)$ : $0.22(2)$ should be read as $0.22 \pm 0.02$

Fitted apparent Young's moduli $E$ values are significantly lower for $\mathrm{R}^{2+}(204-260 \mathrm{GPa})$ compared to $\mathrm{R}^{3+}$ substitutions (441-564 GPa) in both enstatite and ferrosilite. This implies that the crystal structure resists deformation more and points to smaller differences in $D$ values between large and small $\mathrm{R}^{2+}$ cations compared to large and small $\mathrm{R}^{3+}$ cations. From our simulations, there does not appear to be a correlation between Young's modulus and Fe content, consistent with the observed small difference in bulk modulus between ferrosilite and enstatite $(-0.7 \%$ experimentally, $3.9 \%$ computationally, see Table 7).

\section{Discussion}

Comparison of the experimental results to Frei et al. (2009)

When comparing our experimental results at $1 \mathrm{~atm}$ to the high-pressure data of Frei et al. (2009), we find few 

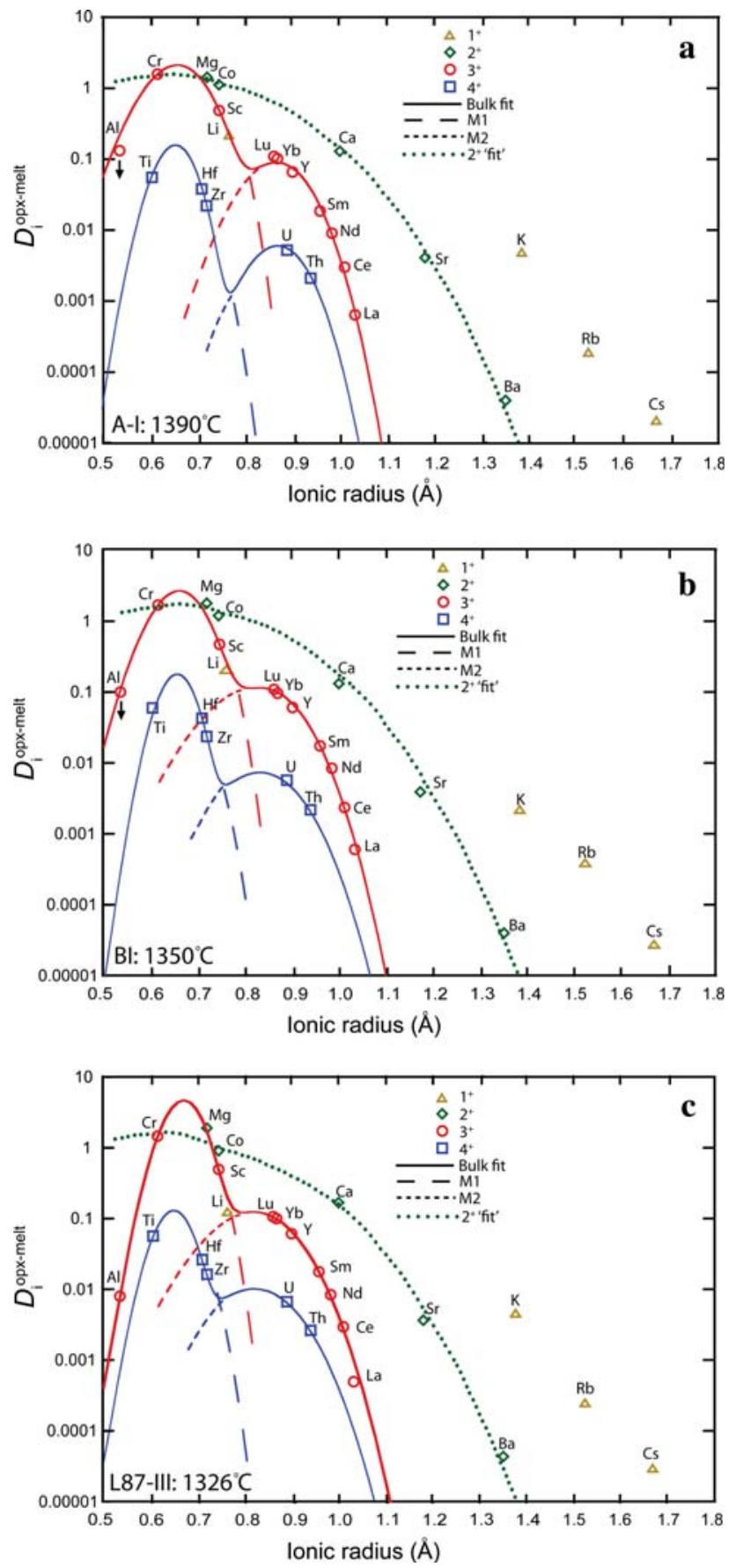

Fig. 3 Onuma diagrams showing partitioning data for the experiments at $1,390^{\circ} \mathrm{C}(\mathbf{a}), 1,350^{\circ} \mathrm{C}(\mathbf{b})$ and $1,326^{\circ} \mathrm{C}(\mathbf{c})$. Solid curves are lattice strain fits to data for $\mathrm{R}^{3+}$ and $\mathrm{R}^{4+}$ cations entering $\mathrm{M} 1$ and $\mathrm{M} 2$ sites using Eq. 9. Dashed lines indicate the shape of individual M1 and $\mathrm{M} 2$ site lattice strain parabolas. Data for the $\mathrm{R}^{2+}$ cations could not be fitted to Eq. 9. The estimated approximate shape of the lattice strain fit is shown by a dotted curve. For the $\mathrm{R}^{+}$cations, only $D$ values are indicated. Because the distribution of $\mathrm{Al}$ between the Opx M1 and $\mathrm{T}$ sites is unknown, the indicated $D_{\mathrm{Al}}^{\mathrm{M} 1}$ is a maximum value

differences. The most prominent difference is the compatibility of $\mathrm{V}$. At atmospheric pressure, $\mathrm{V}$ is incompatible $\left(D_{\mathrm{V}}=0.6\right)$, whilst at high $P(1.1-3.2 \mathrm{GPa})$ it is compatible $\left(D_{\mathrm{V}}=0.9-1.8\right)$. This difference is likely not a $P$ effect, but is related to $f \mathrm{O}_{2}$ differences between the experiments, which used simple Pt capsules as opposed to graphite-lined Pt capsules (Frei et al. 2009). Independently, estimating the partition coefficient for $\mathrm{V}^{5+}$, which is the expected valence state for $\mathrm{V}$ in air, is difficult as there are no enough $\mathrm{R}^{5+}$ elements to predict their partitioning behaviour using lattice strain modelling. From lattice strain modelling, we can conclude however that the expected partition coefficient for $\mathrm{V}^{4+}$ in our experiments would be $\sim 0.05$ (Fig. 3), whereas the expected partition coefficients for $\mathrm{V}^{2+}$ and $\mathrm{V}^{3+}$ would be much higher $(\sim 2$ and $\sim 0.9$, respectively). Clearly $D_{\mathrm{V}}$ is highly dependent on oxidation state.

Other differences include slightly lower compatibilities of $\mathrm{Ti}, \mathrm{Y}, \mathrm{La}, \mathrm{Yb}, \mathrm{Lu}, \mathrm{Cr}$ and $\mathrm{Co}$, whilst $\mathrm{Ta}$, Th and $\mathrm{U}$ have slightly higher $D$ values in the present study. The observed small decrease in fractionation of the HREE compared to the LREE with increasing temperature was also noted in the high-pressure experiments of Frei et al. (2009).

Frei et al. (2009) showed a decrease in compatibility of HFSE elements with increasing $P-T$. We do not observe a general trend across the HFSE. Similar to Frei et al. (2009), we find that $D_{\mathrm{Zr}}^{\mathrm{Opx}-\mathrm{melt}} / D_{\mathrm{Hf}}^{\mathrm{Opx}-\text {-melt }}, D_{\mathrm{Th}}^{\mathrm{Opx}-\text { melt }} / D_{\mathrm{U}}^{\mathrm{Opx}-\text { melt }}$ and $D_{\mathrm{Nb}}^{\mathrm{Opx}-\mathrm{melt}} / D_{\mathrm{Ta}}^{\mathrm{Opx}-\mathrm{melt}}$ are $<1$. We also observe that $D_{\mathrm{Ta}}^{\mathrm{Opx}-\mathrm{melt}}>D_{\mathrm{Nb}}^{\mathrm{Opx}-\text { melt }}$, suggesting that their effective ionic radii differ slightly, with $\mathrm{Nb}$ having a larger ionic radius (Tiepolo et al. 2000; Green et al. 2000; Adam and Green 2006; Frei et al. 2009).

We have shown that for the $\mathrm{R}^{3+}$ and $\mathrm{R}^{4+}$ cations $D_{0}^{\mathrm{M} 1}>D_{0}^{\mathrm{M} 2}$ similar to Frei et al. (2009) where $\mathrm{R}^{2+}, \mathrm{R}^{3+}$ and $\mathrm{R}^{4+}$ data showed $D_{0}^{\mathrm{M} 1}>D_{0}^{\mathrm{M} 2}$. Both data sets show systematically that $E^{\mathrm{M} 1}>E^{\mathrm{M} 2}$ and $E^{\mathrm{M} 1(4+)}>E^{\mathrm{M} 1(3+)}$. In addition, we find $E^{\mathrm{M} 2(4+)}>E^{\mathrm{M} 2(3+)}$, whilst at high $P$ it is opposite. The optimum ionic radii are $0.65-0.67 \AA$ for $r_{0}^{\mathrm{M} 1}$ and $0.82-0.87 \AA$ for $r_{0}^{\mathrm{M} 2}$, similar to the values at high $P$. The range for $r_{0}^{\mathrm{M} 2}$ seems large, when looking at the small variations in $D$ with $T$. This can be explained by the dependence of $E$ on $r_{0}$ and vice versa (Eqs. 5, 9).

Computer simulations and implications of trace element substitution mechanisms

In our computer simulations, we studied homo- and heterovalent substitutions in the enstatite and ferrosilite end-members. Calculated solution energies (Fig. 4) show that $\mathrm{R}^{2+}$ cations are more soluble in Opx than $\mathrm{R}^{3+}$ cations of similar size, consistent with experimentally determined Opx-melt partitioning data. In addition, simulations show charge balancing of $\mathrm{R}^{3+}$ cations by coupled substitution with $\mathrm{Li}^{+}$on the M1 site that is energetically favoured over both coupled substitution involving $\mathrm{Al}-\mathrm{Si}$ exchange on the 
Table 6 Best-fit values for $D_{0}$, $E$ and $r_{0}$ for M1 and M2 lattice site of enstatite for the $\mathrm{R}^{3+}$ and $\mathrm{R}^{4+}$ cations
Numbers in parentheses indicate one standard deviation of replicate analyses in terms of last significant numbers $(1 \sigma)$ : 0.22 (2) should be read as $0.22 \pm 0.02$. No error listed for $r_{0}^{\mathrm{M} 2}$ for $\mathrm{R}^{4+}$ cations since this value was fixed to the value of $\mathrm{R}^{3+}$

\begin{tabular}{llll}
\hline Run ID: & $\mathrm{A} 2$ & $\mathrm{~B} 1$ & L87-III \\
$T\left({ }^{\circ} \mathrm{C}\right):$ & 1,390 & 1,350 & 1,326 \\
\hline$D_{0}^{\mathrm{M} 1}$ & & & \\
$\mathrm{R}^{3+}$ & $2.117(412)$ & $2.677(669)$ & $0.764(667)$ \\
$\mathrm{R}^{4+}$ & $0.156(11)$ & $0.186(16)$ & $0.132(62)$ \\
$D_{0}^{\mathrm{M} 2}$ & & & $0.125(12)$ \\
$\mathrm{R}^{3+}$ & $0.089(3)$ & $0.114(4)$ & $0.0104(25)$ \\
$\mathrm{R}^{4+}$ & $0.0059(1)$ & $0.0076(11)$ & $2,123(163)$ \\
$E^{\mathrm{M} 1}$ & & & $2,485(899)$ \\
$\mathrm{R}^{3+}$ & $998(281)$ & $1,277(349)$ & $388(42)$ \\
$\mathrm{R}^{4+}$ & $2,360(135)$ & $2,773(147)$ & $376(87)$ \\
$E^{\mathrm{M} 2}$ & & & \\
$\mathrm{R}^{3+}$ & $667(15)$ & $471(19)$ & $0.67(0.1)$ \\
$\mathrm{R}^{4+}$ & $809(82)$ & $437(63)$ & $0.65(0.4)$ \\
$r_{0}^{\mathrm{M} 1}$ & & & $0.82(1)$ \\
$\mathrm{R}^{3+}$ & $0.66(0.7)$ & $0.66(0.6)$ & 0.82 \\
$\mathrm{R}^{4+}$ & $0.65(0.3)$ & $0.66(0.1)$ & \\
$r_{0}^{\mathrm{M} 2}$ & & $0.83(0.4)$ & \\
$\mathrm{R}^{3+}$ & $0.87(0.2)$ & 0.83 & \\
$\mathrm{R}^{4+}$ & 0.87 & & \\
\hline & & &
\end{tabular}

Table 7 Comparison between experimental and calculated lattice parameters for enstatite and ferrosilite

\begin{tabular}{|c|c|c|c|c|c|c|c|}
\hline \multirow{3}{*}{$\begin{array}{l}\text { Mineral } \\
\text { Enstatite }\left(\mathrm{MgMgSi}_{2} \mathrm{O}_{6}\right)\end{array}$} & \multicolumn{4}{|c|}{ Lattice parameter $\left(\AA, \AA^{3}\right)$} & \multicolumn{3}{|c|}{ Bulk modulus (GPa) } \\
\hline & \multicolumn{2}{|c|}{ Experimental } & \multirow{2}{*}{$\frac{\text { Calculated }}{17.971}$} & \multirow{2}{*}{$\frac{\text { Deviation }}{-1.44 \%}$} & \multirow{2}{*}{$\begin{array}{l}\text { Experimental } \\
95.8\end{array}$} & \multirow{2}{*}{$\begin{array}{l}\text { Calculated } \\
92.7\end{array}$} & \multirow{2}{*}{$\frac{\text { Deviation }}{-3.2 \%}$} \\
\hline & $a$ & 18.233 & & & & & \\
\hline & $b$ & 8.8191 & 8.666 & $-1.74 \%$ & & & \\
\hline & $c$ & 5.1802 & 5.272 & $1.77 \%$ & & & \\
\hline & $V$ & 832.97 & 821.04 & $-1.43 \%$ & & & \\
\hline \multirow[t]{4}{*}{ Ferrosilite $\left(\mathrm{FeFeSi}_{2} \mathrm{O}_{6}\right)$} & $a$ & 18.417 & 18.348 & $-0.37 \%$ & 95.1 & 96.3 & $1.3 \%$ \\
\hline & $b$ & 9.073 & 8.793 & $-3.09 \%$ & & & \\
\hline & $c$ & 5.239 & 5.323 & $1.60 \%$ & & & \\
\hline & $V$ & 875.42 & 858.78 & $-1.90 \%$ & & & \\
\hline
\end{tabular}

Experimental values for enstatite are from Hugh-Jones and Angel (1994) and for ferrosilite from Hugh-Jones et al. (1997) and Hugh-Jones and Angel (1997)

tetrahedrally coordinated Opx site and coupled substitution with $\mathrm{Rb}^{+}$on the $\mathrm{M} 2$ site

The total amount of $\mathrm{Li}^{+}$present in our experiments is sufficient to charge balance the incorporation of all REE and $\mathrm{Sc}^{3+}$ present. The amount of $\mathrm{Li}^{+}$can also charge balance most $\mathrm{Cr}^{3+}$ (in 1,390 and $1,326^{\circ} \mathrm{C}$ ) or all $\left(1,350^{\circ} \mathrm{C}\right.$ ). Experimental Opx-melt partitioning studies in which $\mathrm{Li}^{+}$ was present (e.g. Dunn and Sen 1994; Adam and Green 2006; McDade et al. 2003; Frei et al. 2009) generally show higher $D$ values for $\mathrm{R}^{3+}$ cations compared to studies in which $\mathrm{Li}^{+}$was absent (e.g. Colson et al. 1988; Schwandt and McKay 1998). Although direct comparison needs to be viewed with caution due to the as yet unknown effects of $P-T-x$ variations between these studies, this may indicate that $\mathrm{Li}^{+}$substitution is indeed an important charge-balancing mechanism in Opx.

Computer simulations versus experiments

The observed kinks in the solution energy plots (Fig. 4) indicate that $\mathrm{R}^{2+}$ cations with an ionic radius larger than $\mathrm{Mg}^{2+}$ for enstatite or $\mathrm{Fe}^{2+}$ for ferrosilite are preferentially incorporated into the M2 site. The coupled heterovalent substitutions of $\mathrm{Li}^{+}$and $\mathrm{R}^{3+}$ mechanism for both enstatite and ferrosilite preferentially incorporate larger REE, e.g. elements larger than $\mathrm{Yb}^{3+}$, on M2. For enstatite, all REE are preferentially incorporated on the M2 site. However, in the experiments, all REE are incorporated on the M2 site. 

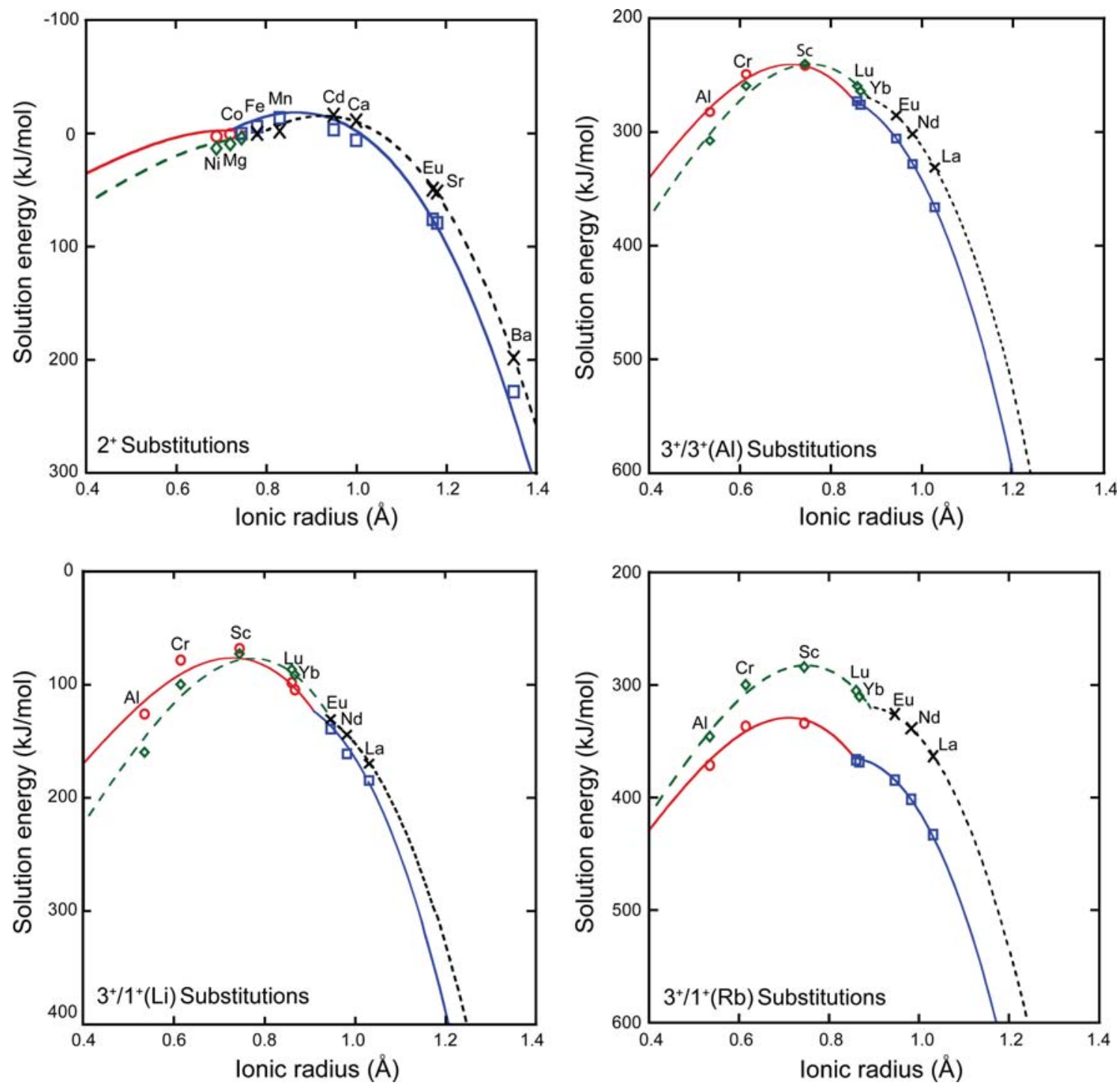

Fig. 4 Dependence of solution energy on ionic radius. Red and blue solid lines present fits to data for the M1 and M2 sites of enstatite, respectively; dashed green and black lines present fits to data for the

Experiments and computer simulations both suggest a clear difference in size between $r_{0}^{\mathrm{M} 1}$ and $r_{0}^{\mathrm{M} 2}$, with the latter being larger. For substitutions of $\mathrm{R}^{3+}$, our experiments show ionic radii of $0.66-0.67 \AA$ (M1) and $0.82-0.87 \AA$ (M2), which are close to the computer simulations which have ideal ionic radii of $\sim 0.71-0.73 \AA$ (M1) and $\sim 0.79$ $0.84 \AA$ (M2) (Table 6).

The lower apparent Young's moduli for substitutions of $\mathrm{R}^{2+}(E=204-260 \mathrm{GPa})$ compared to $\mathrm{R}^{3+}(E=441-$ $564 \mathrm{GPa}$ ) in both enstatite and ferrosilite in our simulations are consistent with experiments (Figs. 3,4). The observed difference in $E^{\mathrm{M} 1}$ and $E^{\mathrm{M} 2}$ for substitutions of $\mathrm{R}^{3+}$ cations in the experiments is not observed in the simulations. Our simulations show rather similar values for $E^{\mathrm{M} 1}$ and $E^{\mathrm{M} 2}$. This difference between experiment and simulation is

M1 and M2 site of ferrosilite, respectively, all using Eq. 8. Note inverted $Y$-axes to facilitate comparison with experimental $D$ values

likely due to the incomplete description of melt thermodynamics inherent in our definition of solution energy (Eqs. 2, 3).

The effect of $\mathrm{Fe}$

The computer simulations suggest an important difference in $r_{0}$ between the M1 and M2 sites of enstatite and ferrosilite, with ferrosilite having systematically larger optimum ionic radii. To investigate whether this difference is identifiable in the currently available experimental Opxmelt database, we identified three previously published Opx-melt partitioning experiments performed at nearidentical $P-T$ conditions with differing bulk $\mathrm{Fe}$ contents. The first experiment is $\mathrm{Fe}$-free at $1.1 \mathrm{GPa}$ and $1,230^{\circ} \mathrm{C}$ 
Table 8 Computer simulated solution energy best-fit values for $r_{0}$ and $E_{x}$ for the M1 and M2 lattice site of enstatite and ferrosilite

\begin{tabular}{|c|c|c|}
\hline & \multicolumn{2}{|c|}{ Solution energy } \\
\hline & $r_{0}$ & $E$ \\
\hline \multicolumn{3}{|c|}{$\mathrm{R}^{2+}$ defects M1 site } \\
\hline Enstatite & $0.712(19)$ & $204(12)$ \\
\hline Ferrosilite & $0.775(13)$ & $207(10)$ \\
\hline \multicolumn{3}{|c|}{$\mathrm{R}^{2+}$ defects M2 site } \\
\hline Enstatite & $0.867(4)$ & $255(6)$ \\
\hline Ferrosilite & $0.926(3)$ & $260(6)$ \\
\hline \multicolumn{3}{|c|}{$\mathrm{R}^{3+}$ defects $\mathrm{M} 1$ site, $\mathrm{Al}$ on $\mathrm{T}$ site } \\
\hline Enstatite & $0.714(3)$ & $531(16)$ \\
\hline Ferrosilite & $0.756(4)$ & $543(26)$ \\
\hline \multicolumn{3}{|c|}{$\mathrm{R}^{3+}$ defects $\mathrm{M} 2$ site, $\mathrm{A} 1$ on $\mathrm{T}$ site } \\
\hline Enstatite & $0.790(0.6)$ & $473(42)$ \\
\hline Ferrosilite & $0.836(0.4)$ & $463(25)$ \\
\hline \multicolumn{3}{|c|}{$\mathrm{R}^{3+}$ defects $\mathrm{M} 1$ site, $\mathrm{Li}$ on $\mathrm{M} 1$ site } \\
\hline Enstatite & $0.729(11)$ & $448(48)$ \\
\hline Ferrosilite & $0.774(4)$ & $525(29)$ \\
\hline \multicolumn{3}{|c|}{$\mathrm{R}^{3+}$ defects $\mathrm{M} 2$ site, $\mathrm{Li}$ on $\mathrm{M} 1$ site } \\
\hline Enstatite & $0.824(5)$ & $477(32)$ \\
\hline Ferrosilite & $0.859(3)$ & $441(15)$ \\
\hline \multicolumn{3}{|c|}{$\mathrm{R}^{3+}$ defects $\mathrm{M} 1$ site, $\mathrm{Rb}$ on $\mathrm{M} 2$ site } \\
\hline Enstatite & $0.711(5)$ & $545(22)$ \\
\hline Ferrosilite & $0.749(4)$ & $564(27)$ \\
\hline \multicolumn{3}{|c|}{$\mathrm{R}^{3+}$ defects $\mathrm{M} 2$ site, $\mathrm{Rb}$ on $\mathrm{M} 2$ site } \\
\hline Enstatite & $0.843(1)$ & $540(9)$ \\
\hline Ferrosilite & $0.881(1)$ & $510(6)$ \\
\hline
\end{tabular}

Numbers in parentheses indicate one standard deviation of replicate analyses in terms of last significant numbers $(1 \sigma)$ : $0.22(2)$ should be read as $0.22 \pm 0.02$

(Frei et al. 2009) performed in a graphite-lined Pt capsule. The produced Opx contained $4.0 \mathrm{wt} \% \mathrm{Al}_{2} \mathrm{O}_{3}$. The second experiment (McDade et al. 2003, hereafter referred to as MD03) was performed at $1.3 \mathrm{GPa}$ and $1,245^{\circ} \mathrm{C}$ in the hydrous Fe-bearing system $\mathrm{Na}_{2} \mathrm{O}-\mathrm{CaO}-\mathrm{Cr}_{2} \mathrm{O}_{3}-\mathrm{FeO}-$ $\mathrm{MgO}-\mathrm{MnO}-\mathrm{Al}_{2} \mathrm{O}_{3}-\mathrm{TiO}_{2}-\mathrm{SiO}_{2}$, producing $\mathrm{Opx}$ with $6.28 \mathrm{wt} \% \mathrm{FeO}$ and $6.88 \mathrm{wt} \% \mathrm{Al}_{2} \mathrm{O}_{3}$. McDade and coworkers used a double-capsule technique buffering $f_{2}$ to $\mathrm{NNO}+1$. The third experiment (Klemme et al. 2006, hereafter referred to as K06) was performed at $1 \mathrm{GPa}$ and $1,200^{\circ} \mathrm{C}$ in an anhydrous $\mathrm{FeO}-\mathrm{MgO}-\mathrm{Al}_{2} \mathrm{O}_{3}-\mathrm{TiO}_{2}-\mathrm{SiO}_{2}$ system, producing Opx with $14.0 \mathrm{wt} \% \mathrm{FeO}$ and $8.6 \mathrm{wt} \%$ $\mathrm{Al}_{2} \mathrm{O}_{3}$. Klemme and co-workers also used graphite-lined $\mathrm{Pt}$ capsules. In addition to the variation in $\mathrm{Fe}$ content, the differences between MD03 and K06 include the percentage of Opx Tschermakite component, the presence of water and $\mathrm{Ca}$ in the former and the absence in the latter.

When comparing the results of these three experiments, we focused specifically on the behaviour of the $\mathrm{R}^{3+}$

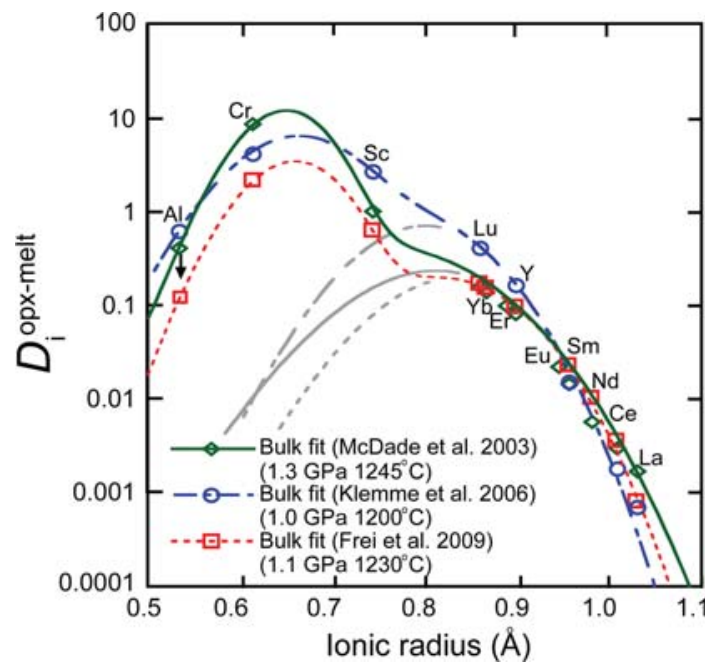

Fig. 5 Comparison of Opx-melt partition coefficient data in the Fefree system (Frei et al. 2009) with two Fe-bearing studies (McDade et al. 2003; Klemme et al. 2006) under similar conditions. Coloured lines show fits of the data to Eq. 9. Fitted curves for the M2 site are shown in grey. Because the distribution of Al between the Opx M1 and $\mathrm{T}$ sites is unknown, the indicated $D_{\mathrm{Al}}^{\mathrm{Ml}}$ is a maximum value

elements, because these elements provide the best constraints on $r_{0}$ values. $\mathrm{R}^{3+}$ data from all three experiments show clear double-parabolic behaviour (Fig. 5). Ideal ionic radii, $r_{0}^{\mathrm{M} 1}$ and $r_{0}^{\mathrm{M} 2}$, are 0.65 and $0.79 \AA$ for $\mathrm{MD} 03$, respectively, and 0.67 and $0.81 \AA$ for K06, respectively, compared to 0.66 and $0.83 \AA$ (Frei et al. 2009). We further find that $D_{0}^{\mathrm{M} 1}$ is larger in the Fe-bearing experiments (5.79 and 11.46) versus the Fe-free experiment (3.54).

Because increasing Opx Fe contents are accompanied by increasing $\mathrm{Al}$ contents in these three experiments, disentangling the effects of $\mathrm{Fe}$ and $\mathrm{Al}$ content on partitioning is difficult. The Opx-melt partitioning data of Adam and Green (2006, not shown in Fig. 5) provide additional insight. The Opx in the hydrous, Fe-bearing experiment performed by Adam and Green (2006) at $2.7 \mathrm{GPa}$, and $1,160^{\circ} \mathrm{C}$, has comparable $\mathrm{Al}_{2} \mathrm{O}_{3}$ content to Frei et al. (2009) and slightly lower values for $D_{0}^{\mathrm{M} 1}$ and $D_{0}^{\mathrm{M} 2}$. Again, the observed $r_{0}^{\mathrm{M} 2}$ of $0.80 \AA$ is smaller than in the Fe-free experiments. The increase in $D_{0}^{\mathrm{M} 1}$ and $D_{0}^{\mathrm{M} 2}$ observed in MD03 and K06 could thus be related to their relatively high Tschermakite content, but the decrease in $r_{0}^{\mathrm{M} 2}$ is more likely related to the higher concentration of $\mathrm{FeO}$. The experiments of Frei et al. (2009), which showed increasing Opx Tschermakite component with increasing $P$, also showed decreasing values for $D_{0}^{\mathrm{M} 1}$ and $D_{0}^{\mathrm{M} 2}$, supporting the conclusion that partition coefficients decrease with increasing Tschermakite component.

In summary, Fe-bearing experimental studies thus appear to show a reduction in ideal size of the M2 site. This seems counter-intuitive since $\mathrm{Fe}^{2+}$ is larger than $\mathrm{Mg}^{2+}$, but the same trend was previously observed in REE 
partitioning between garnet and melt as a function of garnet Fe content (van Westrenen et al. 2000b). To fully understand the role of Fe in the partitioning behaviour of Opx, it is important that systematic experiments are done in the NCFMAS system and NFMAS subsystems. These will help quantify variations in effective ionic radii as a function of iron content, and will be a key step towards deriving Opx-melt partition coefficients applicable to models of terrestrial and lunar magmatic processes.

\section{Conclusions}

Our main conclusions from integrating the experimental results, computer simulations and previous data on Opx partitioning are as follows:

- The general partitioning behaviour of Opx appears largely unaffected by $P$. There are only minor differences between the current experimental data and the high $P-T$ data of Frei et al. (2009).

- Calculated solution energies show that $\mathrm{R}^{2+}$ cations are more soluble in Opx than $\mathrm{R}^{3+}$ of the same size, as observed experimentally. In addition, simulations show charge balancing of $\mathrm{R}^{3+}$ cations by coupled substitution with $\mathrm{Li}^{+}$on the M1 site that is energetically favoured over coupled substitution involving $\mathrm{Rb}^{+}$on the M2 site or Al-Si exchange on the tetrahedrally coordinated Opx site.

- There is a clear difference in ideal ionic radii of Opx $r_{0}^{\mathrm{M} 1}$ and $r_{0}^{\mathrm{M} 2}$ with the latter being the larger site, reflected both in experiments and simulations. The Opx $\mathrm{M}$ site should hence not be considered as a single site in Opx-melt partitioning models.

- Computer simulations suggest that the presence of Fe increases the size of $r_{0}^{\mathrm{M} 1}$ and $r_{0}^{\mathrm{M} 2}$; however, experimental studies dealing with Fe-bearing Opx show a decrease in size of $r_{0}^{\mathrm{M} 2}$. To fully understand the role of Fe in Opx-melt partitioning systematic experiments in simple iron-bearing systems are required.

\footnotetext{
Acknowledgments We would like to thank Alex Corgne and Trevor Green for their comments and suggestions, which significantly improved the manuscript. We thank Stu Parker for useful comments. This work was supported by a EURYI award to WvW. DF and GF thank the DFG for supporting this work by grant number FR 557/17-1 to GF. All experimental work presented here was carried out at the University of Bristol at the Large Scale Geochemical Facility supported by the European Community-Access to Research Infrastructure Action of Improving Human Potential Programme (contract number HPRI-CT-1999-00008 awarded to Prof. B.J. Wood) which is gratefully acknowledged. DF and JB greatly acknowledge access to the NSS Edinburgh ion microprobe facility granted by NERC. We are indebted to John Craven and Richard Hinton for their efforts and help with ion microprobe analysis, and to Oona Appelt (GFZ Potsdam) and Berit Wenzel (University of Copenhagen) for their help with the
}

EMPA. This paper is published with the permission of the Geological Survey of Denmark and Greenland.

Open Access This article is distributed under the terms of the Creative Commons Attribution Noncommercial License which permits any noncommercial use, distribution, and reproduction in any medium, provided the original author(s) and source are credited.

\section{References}

Adam J, Green T (2006) Trace element partitioning between micaand amphibole-bearing garnet lherzolite and hydrous basanitic melt. 1. Experimental results and the investigation of controls on partitioning behaviour. Contrib Mineral Petrol 152:1-17

Barnes SJ (1986) The distribution of chromium among orthopyroxene, spinel and silicate liquid at atmospheric pressure. Geochim Cosmochim Acta 50:1889-1909

Bashir J, Khan RTA, Butt NM, Heger G (2002) Thermal atomic displacement parameters of SrO. Powder Diffr 17:222-224

Bédard JH (2007) Trace element partitioning coefficients between silicate melts and orthopyroxene: parameterizations of $D$ variations. Chem Geol 244:263-303

Bence AE, Albee AL (1968) Empirical correction factors for electron microanalysis of silicates and oxides. J Geol 76:382-403

Blundy JD, Wood BJ (1994) Prediction of crystal-melt partitioncoefficients from elastic-moduli. Nature 372:452-454

Brice JC (1975) Some thermodynamic aspects of growth of strained crystals. J Cryst Growth 28:249-253

Canil D (1999) Vanadium partitioning between orthopyroxene, spinel and silicate melt and the redox states of mantle source regions for primary magmas. Geochim Cosmochim Acta 63:557-572

Catlow CRA, James R, Mackrodt WC, Stewart RF (1982) Defect energetics in alpha- $\mathrm{Al}_{2} \mathrm{O}_{3}$ and rutile $\mathrm{TiO}_{2}$. Phys Rev B 25:10061026

Colson RO, Gust D (1989) Effects of pressure on partitioning of trace-elements between low-Ca pyroxene and melt. Am Miner 74:31-36

Colson RO, McKay GA, Taylor LA (1988) Temperature and composition dependencies of trace-element partitioning-olivine melt and low-Ca pyroxene melt. Geochim Cosmochim Acta 52:539-553

Corgne A, Allan NL, Wood BJ (2003) Atomistic simulations of trace element incorporation into the large site of $\mathrm{Mg}_{2} \mathrm{Si}_{2} \mathrm{O}_{6}$ and $\mathrm{CaSiO}_{3}$ perovskites. Phys Earth Planet Interiors 139:113-127

Cunningham GW (1963) Nuclear poisons. React Mater 6:63-66

Dick BG, Overhauser AW (1958) Theory of the dielectric constants of alkali halide crystals. Phys Rev 112:90-103

Dunn T, Sen C (1994) Mineral/matrix partition-coefficients for orthopyroxene, plagioclase, and olivine in basaltic to andesitic systems-a combined analytical and experimental-study. Geochim Cosmochim Acta 58:717-733

Frei D, Liebscher A, Wittenberg A, Shaw CSJ (2003) Crystal chemical controls on rare-earth-element partitioning between epidote-group minerals and melts: an experimental and theoretical study. Contrib Mineral Petrol 146:192-204

Frei D, Liebscher A, Franz G, Wunder B, Klemme S, Blundy J (2009) Trace element partitioning between orthopyroxene and anhydrous silicate melt on the lherzolite solidus from 1.1 to $3.2 \mathrm{GPa}$ and 1230 to $1535^{\circ} \mathrm{C}$ in the model system $\mathrm{Na}_{2} \mathrm{O}-\mathrm{CaO}-\mathrm{MgO}-$ $\mathrm{Al}_{2} \mathrm{O}_{3}-\mathrm{SiO}_{2}$. Contrib Mineral Petrol 157:473-490

Gale JD (1997) GULP: a computer program for the symmetryadapted simulation of solids. J Chem Soc Faraday Trans 93: 629-637 
Green DH (1971) Composition of basaltic magmas as indicators of conditions of origin - application to oceanic volcanism. Phil Trans R Soc Lond Ser A Math Phys Sci 268:707-725

Green TH, Blundy JD, Adam J, Yaxley GM (2000) SIMS determination of trace element partition coefficients between garnet, clinopyroxene and hydrous basaltic liquids at $2-7.5 \mathrm{GPa}$ and $1080-1200^{\circ} \mathrm{C}$. Lithos 53:165-187

Hinton RW (1990) Ion microprobe trace-element analysis of silicates-measurement of multielement glasses. Chem Geol 83:11-25

Hugh-Jones DA, Angel RJ (1994) A compressional study of $\mathrm{Mg}_{2} \mathrm{Si}_{2} \mathrm{O}_{6}$ orthoenstatite up to $8.5 \mathrm{GPa}$. Am Miner 79:405-410

Hugh-Jones DA, Angel RJ (1997) Effect of $\mathrm{Ca}^{2+}$ and $\mathrm{Fe}^{2+}$ on the equation of state of $\mathrm{Mg}_{2} \mathrm{Si}_{2} \mathrm{O}_{6}$ orthopyroxene. J Geophys Res Solid Earth 102:12333-12340

Hugh-Jones DA, Chopelas A, Angel RJ (1997) Tetrahedral compression in $(\mathrm{Mg}, \mathrm{Fe}) \mathrm{SiO}_{3}$ orthopyroxenes. Phys Chem Miner 24:301310

Kennedy AK, Lofgren GE, Wasserburg GJ (1993) An experimental study of trace element partitioning between olivine, orthopyroxene and melt in chondrules: equilibrium values and kinetic effects. Earth Planet Sci Lett 115:177-195

Klemme S, Gunther D, Hametner K, Prowatke S, Zack T (2006) The partitioning of trace elements between ilmenite, ulvospinel, annalcolite and silicate melts with implications for the early differentiation of the moon. Chem Geol 234:251-263

Lee CTA, Harbert A, Leeman WP (2007) Extension of lattice strain theory to mineral/mineral rare-earth element partitioning: an approach for assessing disequilibrium and developing internally consistent partition coefficients between olivine, orthopyroxene, clinopyroxene and basaltic melt. Geochim Cosmochim Acta 71:481-496

Lewis GV, Catlow CRA (1985) Potential models for ionic oxides. J Phys C Solid State Phys 18:1149-1161

Liebscher A, Franz G, Frei D, Dulski P (2007) High-pressure melting of eclogite and the $P-T-X$ history of tonalitic to trondhjemitic zoisite-pegmatites, Münchberg Massif, Germany. J Petrol 48:1001-1019

Longhi J (1987) Liquidus equilibria and solid-solution in the system $\mathrm{CaAl}_{2} \mathrm{Si}_{2} \mathrm{O}_{8}-\mathrm{Mg}_{2} \mathrm{SiO}_{4}-\mathrm{CaSiO}_{3}-\mathrm{SiO}_{2}$ at low-pressure. Am J Sci 287:265-331

Longhi J, Boudreau AE (1980) The orthoenstatite liquidus field in the system forsterite-diopside-silica at one atmosphere. Am Miner 65:563-573

McDade P, Blundy JD, Wood BJ (2003) Trace element partitioning between mantle wedge peridotite and hydrous $\mathrm{MgO}$-rich melt. Am Miner 88:1825-1831

Nielsen RL, Gallahan WE, Newberger F (1992) Experimentally determined mineral-melt partition-coefficients for Sc, Y and REE for olivine, orthopyroxene, pigeonite, magnetite and ilmenite. Contrib Mineral Petrol 110:488-499

O'Hara MJ (1968) Bearing of phase equilibria studies in synthetic and natural systems on origin and evolution of basic and ultrabasic rocks. Earth Sci Rev 4:69-133

Onuma N, Higuchi H, Wakita H, Nagasawa H (1968) Trace element partition between 2 pyroxenes and host lava. Earth Planet Sci Lett 5:47-51

Papike JJ, Karner JM, Shearer CK (2005) Comparative planetary mineralogy: valence state partitioning of $\mathrm{Cr}, \mathrm{Fe}, \mathrm{Ti}$, and $\mathrm{V}$ among crystallographic sites in olivine, pyroxene, and spinel from planetary basalts. Am Miner 90:277-290

Pouchou JL, Pichoir F (1985) "PAP" $(\phi-\rho-Z)$ procedure for improved quantitative microanalysis. In: Amstrong JT (ed) Microbeam analysis. San Francisco Press, California, pp 104-106
Press WH, Teukolsky SA, Vetterling WT, Flannery BP (1992) Numerical Recipes in C, 2nd edn. Cambridge University Press, Cambridge, $965 \mathrm{pp}$

Prowatke S, Klemme S (2005) Effect of melt composition on the partitioning of trace elements between titanite and silicate melt. Geochim Cosmochim Acta 69:695-709

Prowatke S, Klemme S (2006) Trace element partitioning between apatite and silicate melts. Geochim Cosmochim Acta 70:45134527

Purton JA, Allan NL, Blundy JD, Wasserman EA (1996) Isovalent trace element partitioning between minerals and melts: a computer simulation study. Geochim Cosmochim Acta 60:4977-4987

Purton JA, Allan NL, Blundy JD (1997a) Calculated solution energies of heterovalent cations in forsterite and diopside: implications for trace element partitioning. Geochim Cosmochim Acta 61:3927-3936

Purton JA, Allan NL, Blundy JD (1997b) Impurity cations in the bulk and the 001 surface of muscovite: an atomistic simulation study. J Mater Chem 7:1947-1951

Sanders MJ, Leslie M, Catlow CRA (1984) Interatomic potentials for $\mathrm{SiO}_{2}$. J Chem Soc Chem Commun (19):1271-1273

Schwandt CS, McKay GA (1998) Rare earth element partition coefficients from enstatite/melt synthesis experiments. Geochim Cosmochim Acta 62:2845-2848

Shannon RD (1976) Revised effective ionic-radii and systematic studies of interatomic distances in halides and chalcogenides. Acta Crystallogr A 32:751-767

Shearer CK, Papike JJ (1999) Magmatic evolution of the Moon. Am Min 84:1469-1494

Snyder GA, Taylor LA, Neal CR (1992) A chemical-model for generating the sources of mare basalts-combined equilibrium and fractional crystallization of the Lunar magmasphere. Geochim Cosmochim Acta 56:3809-3823

Taylor SR, Jakes P (1974) The geochemical evolution of the moon. In: Proceedings of the fifth Lunar conference, vol 2, pp 1287-1305

Tiepolo M, Vannucci R, Oberti R, Foley S, Bottazzi P, Zanetti A (2000) $\mathrm{Nb}$ and $\mathrm{Ta}$ incorporation and fractionation in titanian pargasite and kaersutite: crystal-chemical constraints and implications for natural systems. Earth Planet Sci Lett 176:185-201

van Westrenen W, Draper DS (2007) Quantifying garnet-melt trace element partitioning using lattice-strain theory: new crystalchemical and thermodynamic constraints. Contrib Mineral Petrol 154:717-730

van Westrenen W, Blundy J, Wood B (1999) Crystal-chemical controls on trace element partitioning between garnet and anhydrous silicate melt. Am Miner 84:838-847

van Westrenen W, Allan NL, Blundy JD, Purton JA, Wood BJ (2000a) Atomistic simulation of trace element incorporation into garnets - comparison with experimental garnet-melt partitioning data. Geochim Cosmochim Acta 64:1629-1639

van Westrenen W, Blundy JD, Wood BJ (2000b) Effect of $\mathrm{Fe}^{2+}$ on garnet-melt trace element partitioning: experiments in FCMAS and quantification of crystal-chemical controls in natural systems. Lithos 53:189-201

van Westrenen W, Wood BJ, Blundy JD (2001) A predictive thermodynamic model of garnet-melt trace element partitioning. Contrib Mineral Petrol 142:219-234

Wood BJ, Blundy JD (1997) A predictive model for rare earth element partitioning between clinopyroxene and anhydrous silicate melt. Contrib Mineral Petrol 129:166-181

Ziemann MA, Förster HJ, Harlov DE, Frei D (2005) Origin of fluorapatite-monazite assemblages in a metamorphosed, sillimanite-bearing pegmatoid, Reinbolt Hills, East Antarctica. Eur J Miner 17:567-579 